\title{
Fertilization increases the functional specialization of fine roots in deep soil layers for young Eucalyptus grandis trees ${ }^{\text {it }}$
}

\author{
B. Bordron ${ }^{\mathrm{a}}$, A. Robin ${ }^{\mathrm{a}, \mathrm{b}, \mathrm{c}}$, I.R. Oliveira ${ }^{\mathrm{a}}$, J. Guillemot ${ }^{\mathrm{a}, \mathrm{b}, \mathrm{c}}$, J.P. Laclau ${ }^{\mathrm{b}, \mathrm{c}, \mathrm{d}}$, C. Jourdan ${ }^{\mathrm{b}, \mathrm{c}}$, \\ Y. Nouvellon ${ }^{\mathrm{a}, \mathrm{b}, \mathrm{c}}$, C.H. Abreu-Junior ${ }^{\mathrm{e}}$, P.C.O. Trivelin ${ }^{\mathrm{e}}$, J.L.M. Gonçalves ${ }^{\mathrm{a}}$, C. Plassard ${ }^{\mathrm{c}, \mathrm{f}}$, \\ J.P. Bouillet ${ }^{\mathrm{a}, \mathrm{b}, \mathrm{c}, *}$ \\ a USP-ESALQ, 13400-970 Piracicaba, SP, Brazil \\ ${ }^{\mathrm{b}}$ CIRAD, UMR Eco\&Sols, F-34398 Montpellier, France \\ ${ }^{\mathrm{c}}$ Eco\&Sols, Univ Montpellier, CIRAD, INRA, IRD, Montpellier SupAgro, Montpellier, France \\ d UNESP, Departamento de Solos e Recursos Ambientais, Universidade Estadual Paulista 'Júlio de Mesquita Filho', 18610-300 Botucatu, SP, Brazil \\ e USP-CENA, 13416-000 Piracicaba, SP, Brazil \\ f INRA, CIRAD, IRD, Montpellier SupAgro, University of Montpellier, UMR Eco\&Sols, F34060 Montpellier, France
}

\section{A R T I C L E I N F O}

\section{Keywords:}

Deep fine roots

${ }^{15} \mathrm{~N}$

Nutrient uptake potential

Rubidium

Sandy tropical soil

Strontium

\begin{abstract}
A B S T R A C T
Functional specialization of fine roots was found for Eucalyptus grandis trees at harvesting age (6 years) on tropical soils. Aiming to elucidate whether functional specialization is a ubiquitous feature of eucalypts, we focused on its changes with ontogeny, tree nutrient status and soil depth. We studied the potential uptake of $\mathrm{N}, \mathrm{K}$ and Ca by 2-year-old $E$. grandis trees, as a function of soil depth and NPK fertilization. We injected $\mathrm{NO}^{-3}{ }_{-}^{15} \mathrm{~N}_{\text {, }}$ $\mathrm{Rb}^{+}\left(\mathrm{K}^{+}\right.$analogue $)$and $\mathrm{Sr}^{2+}\left(\mathrm{Ca}^{2+}\right.$ analogue $)$ tracers simultaneously in a solution at depths of $10,50,150$ and $300 \mathrm{~cm}$ in a sandy Ferralsol soil. A complete randomized block design was set up with three replicates of paired trees per injection depth, in fertilized and non-fertilized plots. Recently expanded leaves were sampled at 70 days after tracer injection. Determination of foliar $\mathrm{Rb}, \mathrm{Sr}$ concentrations and $\mathrm{x}\left({ }^{15} \mathrm{~N}\right)$ allowed estimating the relative uptake potential (RUP) and the specific RUP (SRUP), defined as the ratio between RUP and fine root length density (RLD) in the corresponding soil layer. Various root traits were measured at each depth. Foliar N and $\mathrm{K}$ concentrations were higher in fertilized than in non-fertilized trees. The RUP of $\mathrm{NO}_{3}{ }^{-}{ }^{15} \mathrm{~N}$ decreased sharply with soil depth and the highest values of the SRUP of $\mathrm{NO}_{3}{ }^{-}{ }^{-15} \mathrm{~N}$ were found at a depth of $50 \mathrm{~cm}$. The RUP of Rb ${ }^{+}$and $\mathrm{Sr}^{2+}$ did not change with soil depth, whilst the SRUP of $\mathrm{Rb}^{+}$and $\mathrm{Sr}^{2+}$ were higher at the depth of $300 \mathrm{~cm}$ than in the topsoil, concomitant with an increase in root diameter and a decrease in root tissue density with depth. The SRUP of $\mathrm{Rb}^{+}$and $\mathrm{Sr}^{2+}$ at a depth of $300 \mathrm{~cm}$ were on average 136 and $61 \%$ higher for fertilized trees than for non-fertilized trees, respectively. Fine roots of young $E$. grandis trees showed contrasting potential uptake rates with soil depth depending on the nutrient. Fertilization increased the uptake rate of $\mathrm{Rb}^{+}$and $\mathrm{Sr}^{2+}$ by unit of root length in deep soil layers. Functional specialization of fine roots for cations of low mobility depending on depth previously shown at harvesting age also occurs in young E. grandis plantations and increases with fertilization application. This mechanism helps explaining very low amounts of cations lost by leaching in Eucalyptus plantations established in deep tropical soils, even in highly fertilized stands.
\end{abstract}

\section{Introduction}

Forest plantations accounted in 2015 for some 291 million hectares ( $7 \%$ of the world forest areas), (FAO, 2015) and play an increasing role to satisfy the increase in global wood demand (Keenan et al., 2015; Paquette and Messier, 2010). Eucalypt plantations cover about 20 million hectares around the world and are expanding rapidly in tropical and subtropical regions to provide raw material for wood, paper, and biofuel products as well as large amounts of firewood and charcoal for domestic uses (Booth, 2013). Eucalyptus grandis Hill ex Maiden, is one of the most planted Eucalyptus species owing to its high productivity (Stape et al., 2010), and adaptation to various environments (Binkley et al., 2017; Costa et al., 2017).

High productivity of commercial eucalypt plantations in Brazil

\footnotetext{
This article is part of the Special Issue "Roots and Rhizospheres in Forest Ecosystems: Recent Advances and Future Challenges" published at the journal Forest Ecology and Management 431, 2018.

* Corresponding author at: Laboratoire des RadioIsotopes, Route d'Andraisoro, 101 Antananarivo, Madagascar.

E-mail address: jpbouillet@cirad.fr (J.P. Bouillet).
} 
largely depends on nitrogen $(\mathrm{N})$, phosphorus $(\mathrm{P})$ and potassium $(\mathrm{K})$ applications (Gonçalves et al., 2013). However, the potential negative environmental impacts of fertilizers might limit their use in eucalypt plantations in the future (Brunelle et al., 2015). Even though fertilizers are applied in the topsoil, significant amounts of $\mathrm{K}$ and $\mathrm{N}$ are leached and taken up by Eucalyptus trees down to a depth of $3 \mathrm{~m}$ (Laclau et al., 2010). Fine roots, usually defined according to a diameter-based cut-off $\leq 2 \mathrm{~mm}$ (Freschet et al., 2017) play a major role in the capture and transport of water and nutrients needed for plant growth (Pregitzer et al., 2002; McCormack et al., 2015; Fort et al., 2017). Although tree fine roots are usually more abundant in the shallow soil layers than in depth (Brassard et al., 2009; Laclau et al., 2013; Pinheiro et al., 2016), their presence was observed in very deep soil layers in tropical or subtropical fast-growing plantations and natural forests (Nepstad et al., 1994; Christina et al., 2017; Germon et al., 2017; Fan et al., 2017), e.g. $17 \mathrm{~m}$ deep in 3.5 year-old Eucalyptus plantation in Brazil (Christina et al., 2011). The physiological function of deep fine roots is still questioned (Al Afas et al., 2008; Maeght et al., 2013). Deep-rooting is an important strategy to increase the amount of water available for the trees, and to cope with seasonal droughts (Maeght et al., 2013; Christina et al., 2017; Broedel et al., 2017; Fan et al., 2017). However, the processes that control the uptake of ions such as $\mathrm{NO}_{3}^{-}, \mathrm{K}^{+}$or $\mathrm{Ca}^{2+}$ in very deep soil layers are still poorly understood in forest ecosystems (Iversen, 2010; Hinsinger et al., 2011; Binkley, 2015). Such information would be useful to assess the need to apply fertilization at various dates after planting (Laclau et al., 2010).

Various factors drive nutrient uptake by tree roots, including soil nutrient availability, ion mobility in soil solutions, root traits or root ion transporters (Chapman et al., 2012; Costa et al., 2017; Kulmatiski et al., 2017). Contrasting potential uptake rates with depth depending on the nutrient were found for Quercus robur L., Fagus sylvatica L. and Picea abies (L.) Karst. in Northern Europe (Göransson et al., 2007, 2008) and for E. grandis in Brazil (da Silva et al., 2011). Fine roots of mature $E$. grandis trees exhibited, by unit of root length, greater uptake capacity of $\mathrm{Rb}^{+}$(analogue of $\mathrm{K}^{+}$) and $\mathrm{Sr}^{2+}$ (analogue of $\mathrm{Ca}^{2+}$ ) at a depth of $3 \mathrm{~m}$ than in the topsoil (da Silva et al., 2011). By contrast, a specialization of upper fine roots was likely in $\mathrm{NO}_{3}{ }^{-}$uptake. These results found at harvesting age were consistent in dry and wet seasons, for clayey and sandy soils. However, no information is available for young trees and the consequences of tree nutrient status on the functional specialization of fine roots are still unknown. Root specialization might be explained by many factors, as changes in specific transporter activity and mass flow rates from the soil to the roots through changes in root hydraulic conductivity (Costa et al., 2017). High-affinity transporters in plant, such as $\mathrm{K}$ and $\mathrm{N}$-transporters, can be activated at very low nutrient concentrations allowing efficient nutrient uptake (Schachtman and Schroeder, 1994; Kiba and Krapp, 2016). On the opposite, Bao et al. (2011) showed that AtNRT2.1, an inducible high-affinity $\mathrm{NO}_{3}{ }^{-}$transporter in Arabidpsis thaliana was upregulated by phosphate and sulphate supply. Higher nutrient availability can increase tree nutrient uptake as shown for $E$. grandis (Rowe et al., 2008; Costa et al., 2017).

Moreover, to the best of our knowledge, no specific root functional traits have been associated with the functional specialization of Eucalyptus fine roots along the soil profile. Water and nutrient availabilities are highly dependent on soil depth in tropical eucalypt plantations (Mareschal et al., 2013; Versini et al., 2014). This heterogeneity throughout the soil profile leads to contrasting root functional traits that are highly sensitive to heterogeneous resource distributions (Ostonen et al., 2007). Prieto et al. (2015) measured root functional traits in 20 plant communities located in 3 climatic zones (tropical, Mediterranean and montane) along a land-use gradient. Fine roots exhibited different suites of functional traits (e.g. root diameter or Specific Root Length, SRL) at different soil depths suggesting a difference in root function and foraging capacity. Roots with higher SRL were found in less fertile soils. Pate et al. (1995) showed for Australian species that deep roots had conductivities up to 15 times higher than roots of similar diameter in the topsoil layers, which could help to explain the ability of Eucalyptus trees to use efficiently the resources in deep soil layers despite very low fine root densities.

The study set out to assess the potential uptake of N, K and Ca by 20month-old $E$. grandis trees as a function of soil depth and fertilization at planting. We used $\mathrm{NO}_{3}{ }^{-}{ }^{15} \mathrm{~N}, \mathrm{Rb}^{+}$and $\mathrm{Sr}^{2+}$ tracers simultaneously injected close to trees, at several depths down to $3 \mathrm{~m}$, in a completely randomized experiment including NPK-fertilized and control (non-fertilized) plots. We hypothesized: (i) a functional specialization of fine roots for young eucalypt trees with higher potential uptake rate (per unit of fine root length) for $\mathrm{NO}_{3}{ }_{-}^{-15} \mathrm{~N}$ in the surface soil and for $\mathrm{Rb}^{+}$and $\mathrm{Sr}^{2+}$ in the deep soil layers, as shown in mature eucalypt plantations, and (ii) an increase in functional specialization of fine roots when tree nutrient status is improved by fertilization.

\section{Materials and methods}

\subsection{Study site}

The study was carried out in the Itatinga experimental station of São Paulo University $\left(23^{\circ} 02^{\prime} \mathrm{S}, 48^{\circ} 38^{\prime} \mathrm{W}\right)$, at $860 \mathrm{~m}$ above mean sea level. Over the 15 years prior to planting, the mean annual rainfall was $1360 \mathrm{~mm}$, with a dry and cold season from June to September. The soils are very deep Ferralsols according to FAO classification (FAO, 2014) developed on Cretaceous sandstone with a water table at a depth of approximatively $17 \mathrm{~m}$ (Christina et al., 2011). Soil chemical analyses down to a depth of $3 \mathrm{~m}$ are given in Table 1 .

\subsection{Experimental design}

The experiment was conducted in a complete randomized block design with three blocks and two treatments. Seedlings were planted at a density of 1111 trees ha $^{-1}$ ( $3 \mathrm{~m} \times 3 \mathrm{~m}$ spacing) on May 2014. Each plot had a total area of $48 \mathrm{~m} \times 48 \mathrm{~m}$ and an inner plot of $36 \mathrm{~m} \times 36 \mathrm{~m}$ with two buffer rows. Within each block, there were plots of $E$. grandis without $(\mathrm{F}-)$ or with fertilization $(\mathrm{F}+)$ applied at planting: $125 \mathrm{~kg} \mathrm{ha}^{-1} \mathrm{P}, 121 \mathrm{~kg} \mathrm{ha}^{-1} \mathrm{~N}, 136 \mathrm{~kg} \mathrm{ha}^{-1} \mathrm{~K}, 45 \mathrm{~kg} \mathrm{ha}^{-1} \mathrm{~B}$ and $30 \mathrm{~kg} \mathrm{ha}^{-1}$ FTE (Fritted Trace Element, micronutrients). Factorial fertilization trials at the study site showed that the amounts of nutrients applied were non-limiting for Eucalyptus tree growth (Laclau et al., 2009). Fertilizers were dug into the soil below each tree. Higher N and $\mathrm{K}$ concentrations were found in leaves of fertilized than non-fertilized trees (Table S1). The study was carried out on January 2016, at 20 months of age during the rainy period. The tracers were applied at four depths (i.e. 10, 50, 150 and $300 \mathrm{~cm}$ ) in each block, in both $\mathrm{F}+$ and $\mathrm{F}-$ treatments. For each depth, $\mathrm{NO}_{3}{ }^{-}{ }^{15} \mathrm{~N}_{\mathrm{Rb}^{+}}$and $\mathrm{Sr}^{2+}$ tracers were injected together into seven holes around two neighbouring Eucalyptus trees with the same basal area as the average of the stand (da Silva et al., 2011). The position of the holes was $1 / 4(0.75 \mathrm{~m})$ and $1 / 2(1.5 \mathrm{~m})$ of the inter row on both sides of the planting row, at mid-distance $(1.5 \mathrm{~m})$ from the two sampled trees in the planting row and at mid-distance $(1.5 \mathrm{~m})$ from the two nearest neighbours in the planting row (Fig. 1). The pairs of trees were located more than $16 \mathrm{~m}$ apart to prevent root competition for nutrient uptake. Gravimetric water contents (around $10 \%$ ) were not significantly different between treatments regardless of the depths.

\subsection{Tracer application}

A labelled solution was prepared in the laboratory, one day before application. $\mathrm{RbCl}(100 \mathrm{~g}), \mathrm{SrCl}_{2}(215 \mathrm{~g})$ and $\mathrm{NH}_{4}{ }^{-1} \mathrm{NO}_{3}$ (10 atom\% $\left.\mathrm{NO}_{3-}{ }^{15} \mathrm{~N}\right)(652 \mathrm{~g})$ were dissolved in $3360 \mathrm{~mL}$ of distilled water. The solution was maintained at a temperature of $4{ }^{\circ} \mathrm{C}$ until application in the field. Holes were drilled down to the target application depth using a 35-mm diameter stainless steel auger. A 25-mm diameter PVC tube was inserted into each hole to avoid contamination of upper soil layers 


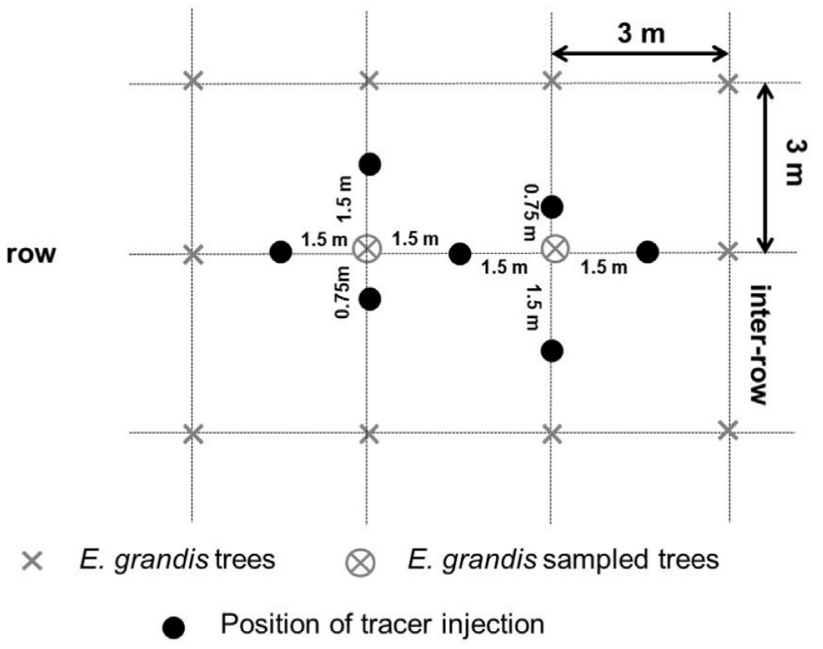

Fig. 1. Layout of the positions where tracers were injected for each depth and each pair of sampled trees. Leaf samples were collected from the same pair of trees (adapted from da Silva et al., 2011).

during tracer application. A 4-mm diameter polyethylene tube, attached to an iron rod, was inserted into the PVC tube and $20 \mathrm{~mL}$ of the labelled solution was injected at the selected depth. Then, $10 \mathrm{ml}$ of distilled water was injected to rinse the syringe and the polyethylene tube. At each position we injected $0.42 \mathrm{~g}$ of $\mathrm{Rb}^{+} ; 0.42 \mathrm{~g}$ of $\mathrm{Sr}^{2+}$ and $0.07 \mathrm{~g}$ of ${ }^{15} \mathrm{~N}$. The nutrient concentration in the $30 \mathrm{ml}$ of solution injected was $0.16 \mathrm{~m}$ for $\mathrm{Rb}^{+}, \mathrm{Sr}^{2+}$ and $\mathrm{NO}_{3}{ }^{-1}{ }^{15} \mathrm{~N}$, and $1.50 \mathrm{~m}$ for $\mathrm{N}$. Finally, the holes were filled with the soil removed during drilling, respecting the original order of the soil horizons (da Silva et al., 2011).

\subsection{Leaf sampling}

Young fully expanded leaves were collected from the upper half of the tree crown of each pair of sampled trees (mean total height of $10.2 \mathrm{~m}$ for $\mathrm{F}+$ and $7.2 \mathrm{~m}$ for $\mathrm{F}-$ ). $\mathrm{Rb}^{+}$and $\mathrm{Sr}^{2+}$ concentrations and $\mathrm{x}$ $\left({ }^{15} \mathrm{~N}\right)$ background values, as well as $\mathrm{N}, \mathrm{P}, \mathrm{K}$ and Ca concentrations were estimated for each pair of trees (48 trees in total) by sampling 10 leaves per tree before tracer application. Forty leaves (20 per labelled trees) were collected for each pair of trees, 70 days after tracer application (da Silva et al., 2011). The leaves were washed in deionized water, dried for 3 days at $65{ }^{\circ} \mathrm{C}$ and stored in sealed acrylic bottles until chemical and isotopic analysis; $x\left({ }^{15} \mathrm{~N}\right)$ and $\mathrm{N}$ concentration were determined with a 20-20 Hydra mass spectrometer coupled to an automatic $\mathrm{N}$ analyser (ANCA-GSL, SERCON Co., Crewe, UK) from $10 \mathrm{mg}$ of leaf powder dry matter. The concentrations of $\mathrm{Rb}^{+}$and $\mathrm{Sr}^{2+}$ were determined by inductively coupled plasma mass spectrometry (ICP-MS Agilent 7500ce; Agilent Technologies, Tokyo, Japan) after sample acid digestion using $0.5 \mathrm{~g}$ of leaf powder in a mixture of $5 \mathrm{~mL}$ of nitric acid $(16 \mathrm{M})$ and $1 \mathrm{ml}$ of perchloric acids (12 M). The limit of detection for $\mathrm{Rb}^{+}$and $\mathrm{Sr}^{2+}$ was 0.018 and $0.020 \mathrm{mg} \mathrm{kg}^{-1}$ respectively. The relative standard deviation was less than $0.5 \%$. The precision of isotope measurements was $0.001 \mathrm{x}$ $\left({ }^{15} \mathrm{~N}\right)$.

\subsection{Root sampling and root traits measurements}

Fine roots (diameter $<2 \mathrm{~mm}$ ) were sampled on March 2016, at 22 months of age in each block, in F+ and F- treatments. Soil cores were collected at 4 positions randomly distributed around 4 trees of mean stand basal area (4 sampling positions per treatment and block) in the plots where tracers were injected (Fig. S1). At each sampling position, soil layers $0-20,40-60,130-170 \mathrm{~cm}$ were collected using a cylindrical auger with an inner diameter of $4.5 \mathrm{~cm}$. In the same holes previously enlarged down to $170 \mathrm{~cm}$ depth using a tool designed to dig 
deep holes (Germon et al., 2017), soil cores between 280 and $320 \mathrm{~cm}$ were collected using a cylindrical auger with an inner diameter of $6.0 \mathrm{~cm}$, using the methodology described by Christina et al. (2011). Each soil sample was weighted in the laboratory and the soil water content was measured (drying $10 \mathrm{~g}$ of soil at $105^{\circ} \mathrm{C}$ for $72 \mathrm{~h}$ ). Each soil sample was homogenously mixed before being divided into two subsamples representing approximatively $10 \%$ and $90 \%$ of the total soil mass. All the roots were recovered from both sub-samples of soil and carefully washed under tap water using sieves (with mesh sizes ranging from 1.19 to $0.50 \mathrm{~mm}$ ) to be free of soil (Cornelissen et al., 2003). Living roots, identified from a white stele (central part of the root) and a good flexibility (ability to return to the original form when curved), were separated from dead roots that were discarded. The biomass of fine roots (with a length $<1 \mathrm{~cm}$ ) was estimated in the subsample representing $10 \%$ of the soil. All the living fine roots (with a length $>1$ $\mathrm{cm}$ in both soil samples) were scanned (800 dpi resolution) and root lengths, areas and diameter were estimated using the WinRHIZO Version Pro V.2009c software (Regent Instruments, QC, Canada). Fine roots were then dried at $65^{\circ} \mathrm{C}$ for $72 \mathrm{~h}$ and weighed ( $\pm 0.1 \mathrm{mg}$ ). Dry masses, lengths and areas of fine roots were used to estimate the following root parameters: specific root length (SRL, ratio between length of scanned fine roots and their dry mass), specific root area (SRA, ratio between area of scanned fine roots and their dry mass) and fine root diameter (Maurice et al., 2010), for each soil layer, sampling position, treatment, and block (96 samples in total). Fine root mass density (RMD) was calculated by dividing root dry matter by dry weight of soil sample, and was then expressed in $\mathrm{g}$ of root per $\mathrm{cm}^{3}$ of soil using soil bulk densities measured in each plot in a pit down to a depth of $3 \mathrm{~m}$. Root length density (RLD) and root area density (RAD) were then calculated for each soil sample by multiplying RMD by SRL and SRA, respectively. The root tissue density was calculated as the ratio of mass per volume according to Wurzburger and Wright (2015).

\subsection{RUP and SRUP calculations}

Leaf concentrations of $\mathrm{Rb}^{+}$and $\mathrm{Sr}^{2+}$ and $\mathrm{x}\left({ }^{15} \mathrm{~N}\right)$ were analysed for all samples of each treatment in the 3 blocks.

The RUP (Root Uptake Potential) was calculated according to da Silva et al. (2011):

$$
\begin{aligned}
\operatorname{RUP}_{i p}(\%)= & \left(\mathrm{T}_{i p}-\mathrm{T}_{i 0}\right) /\left[\left(T_{i 10}-\mathrm{T}_{i 0}\right)+\left(\mathrm{T}_{i 50}-\mathrm{T}_{i 0}\right)+\left(\mathrm{T}_{i 150}-\mathrm{T}_{i 0}\right)+\left(\mathrm{T}_{i 300}-\mathrm{T}_{i 0}\right)\right] \\
& \times 100
\end{aligned}
$$

where $\operatorname{RUP}_{i p}$ was the RUP of tracer $i$ at depth $p, \mathrm{~T}_{i p}$ was the foliar concentration (Rb and $\mathrm{Sr}$ ) or $\mathrm{x}\left({ }^{15} \mathrm{~N}\right)$ of tracer $i$ at depth $p, \mathrm{~T}_{i o}$ was the background value of foliar concentration (Rb and $\mathrm{Sr}$ ) or $x\left({ }^{15} \mathrm{~N}\right)$, and $\mathrm{T}_{i 10}, \mathrm{~T}_{i 50}, \mathrm{~T}_{i 150}, \mathrm{~T}_{i 300}$ were the foliar concentrations or $\mathrm{x}\left({ }^{15} \mathrm{~N}\right)$ of tracer $\mathrm{i}$ at the depths of $10,50,150$ and $300 \mathrm{~cm}$. For each tracer we divided the enrichment at a chosen depth by the enrichment at all depths in the same plot (for each treatment in each block).

The SRUP (Specific Root Uptake Potential) was calculated in each block for both treatments (da Silva et al., 2011):

$\operatorname{SRUP}_{i p}\left(\% \mathrm{~cm}^{-1} \mathrm{~cm}^{3}\right)=\mathrm{RUP}_{i p} / \mathrm{RLD}_{p}$

where SRUP ${ }_{i p}$ was the SRUP of tracer $i$ at depth $p$ and $\operatorname{RLD}_{p}$ was the fine root length density at depth $p$.

For each treatment, each depth, and each block, mean RLD values ( $\mathrm{n}=4$ ) were calculated on the $10 \mathrm{~cm}$ above and below the depths of $10 \mathrm{~cm}$ and $50 \mathrm{~cm}$, and on the $20 \mathrm{~cm}$ above and below the depths of 150 and $300 \mathrm{~cm}$ to account for the lower density of fine roots in deeper soil layers.

\subsection{Statistical analysis}

Generalized linear models (GLM) with binomial distribution and log-link function were used to (1) evaluate the effect of soil depth and fertilization treatment on fine root distributions, fine root traits, RUP and SRUP, and (2) compare the RUP and SRUP of the three tracers $\left(\mathrm{NO}_{3}{ }^{-}{ }^{15} \mathrm{~N}, \mathrm{Rb}^{+}, \mathrm{Sr}^{2+}\right)$ along the soil profiles. The significance of principal and interaction effects was conducted by nested model comparisons using likelihood ratio tests (D) (Zuur et al., 2009). For root distribution and root traits $(n=12)$, soil depth was introduced in the models as categorical variable, and post hoc Wald tests $(\mathrm{W})$ were performed to assess differences between fertilization treatments or among tracers at the different depth levels. For RUP and SRUP $(n=3)$, depth was introduced in the models as continuous variable in order to increase model's degrees of freedom and statistical power, as recommended in small dataset analyses (Zuur et al., 2009). In such case, dependent variables were log-transformed when needed in order to linearize the relationships, and post hoc tests on the significance of depth effect were conducted using Student's t-tests (t). A statistical significance of the depth $*$ fertilization interaction on RUP or SRUP would indicate that their distributions along the soil profile differ between fertilization treatments. Homoscedasticity and normality of all the model's residuals were evaluated using Levene's tests and Kolmogorov-Smirnov tests, respectively. Analyses were performed using the R software version 3.2.2 (R development Core Team, 2013).

\section{Results}

\subsection{Fine root distributions}

Fine root mass density (RMD) was significantly influenced by depth ( $\mathrm{D}=321.8 ; \mathrm{P}<0.01$ ) but not by fertilization. RMD decreased sharply from depths of 10 to $50 \mathrm{~cm}$ with mean values of $0.93 \times 10^{-3}$ and $0.14 \times 10^{-3} \mathrm{~g} \mathrm{~cm}^{-3}$, respectively (Fig. 2a), and then slowly with mean values of $0.13 \times 10^{-3} \mathrm{~g} \mathrm{~cm}^{-3}$ at $150 \mathrm{~cm}$ and $0.06 \times 10^{-3} \mathrm{~g} \mathrm{~cm}^{-3}$ at $300 \mathrm{~cm}$. We report a significant depth $\mathrm{x}$ fertilization interaction ( $\mathrm{D}=22.09 ; \mathrm{P}<0.01)$ that was ascribed to significantly higher RMDs at a depth of $150 \mathrm{~cm}$ for fertilized $(\mathrm{F}+)$ than non-fertilized $(\mathrm{F}-)$ trees ( $\mathrm{W}=-3.19 ; \mathrm{P}<0.01$ ), the opposite being found at a depth of $300 \mathrm{~cm}$ $(\mathrm{W}=3.5 ; \mathrm{P}<0.001)$. Root length density (RLD) was significantly influenced by depth $(\mathrm{D}=484.6 ; \mathrm{P}<0.01)$ and fertilization $(\mathrm{D}=5$; $\mathrm{P}<0.05)$. Consistently to RMD, RLD decreased sharply from the depths of 10 to $50 \mathrm{~cm}$ and then gently down to the depth of $300 \mathrm{~cm}$ (Fig. 2b). The RLDs at the depths of 50, 150 and $300 \mathrm{~cm}$ accounted on average for $13 \%, 8 \%$ and $3 \%$ of the RLD at a depth of $10 \mathrm{~cm}$. Mean RLDs across the sampled depths were $26 \%$ higher in $\mathrm{F}+$ than in $\mathrm{F}-$, with significant differences between treatments at $50 \mathrm{~cm}$ depth $(\mathrm{W}=-2.38$; $\mathrm{P}<0.02)$ and $150 \mathrm{~cm}$ depth $(\mathrm{W}=-2.13 ; \mathrm{P}<0.05)$. A significant depth $\mathrm{x}$ fertilization interaction $(\mathrm{D}=7.58 ; \mathrm{P}<0.05)$ was the result of lower RLD for $\mathrm{F}+$ than $\mathrm{F}-$ at $300 \mathrm{~cm}$ with mean values of 0.08 and $0.10 \mathrm{~cm} \mathrm{~cm}^{-3}$, respectively.

Root area density (RAD) calculated for each sampled soil layer was significantly influenced by depth $(\mathrm{D}=462.62$; $\mathrm{P}<0.01)$ but not by fertilization. RAD value at $10 \mathrm{~cm}$ was 10 times higher than the average of the three other depths (Fig. 2c). A significant depth $\mathrm{x}$ fertilization interaction $(\mathrm{D}=22.09$; $\mathrm{P}<0.01)$ was the result of significant higher $\mathrm{RAD}$ at a depth of $150 \mathrm{~cm}$ for $\mathrm{F}+$ than $\mathrm{F}-(\mathrm{W}=-2.58$; $\mathrm{P}<0.02)$, the opposite being found at $300 \mathrm{~cm}$ depth $(\mathrm{W}=2.8$; $\mathrm{P}<0.01)$.

\subsection{Fine root traits}

Specific root length (SRL) was significantly influenced by depth $(\mathrm{D}=16.82 ; \mathrm{P}<0.01)$ and fertilization $(\mathrm{D}=9.31 ; \mathrm{P}<0.01)$. SRLs values were on average $32 \mathrm{mg}^{-1}$ at $10-50 \mathrm{~cm}$ and $23 \mathrm{mg}^{-1}$ at $150-300 \mathrm{~cm}$ (Fig. 2d). SRL values were always higher in $\mathrm{F}+$ than in $\mathrm{F}-$, with a significant difference at a depth of $300 \mathrm{~cm}$. We report a significant depth $\times$ fertilization interaction $(\mathrm{D}=10.12$; $\mathrm{P}<0.02)$ that was ascribed to a higher variability in SRL with depth in $\mathrm{F}+$ than in $\mathrm{F}-$. Specific root area (SRA) was significantly influenced by fertilization ( $\mathrm{D}=4.84 ; \mathrm{P}<0.05)$ but not by depth. On average, SRAs were 

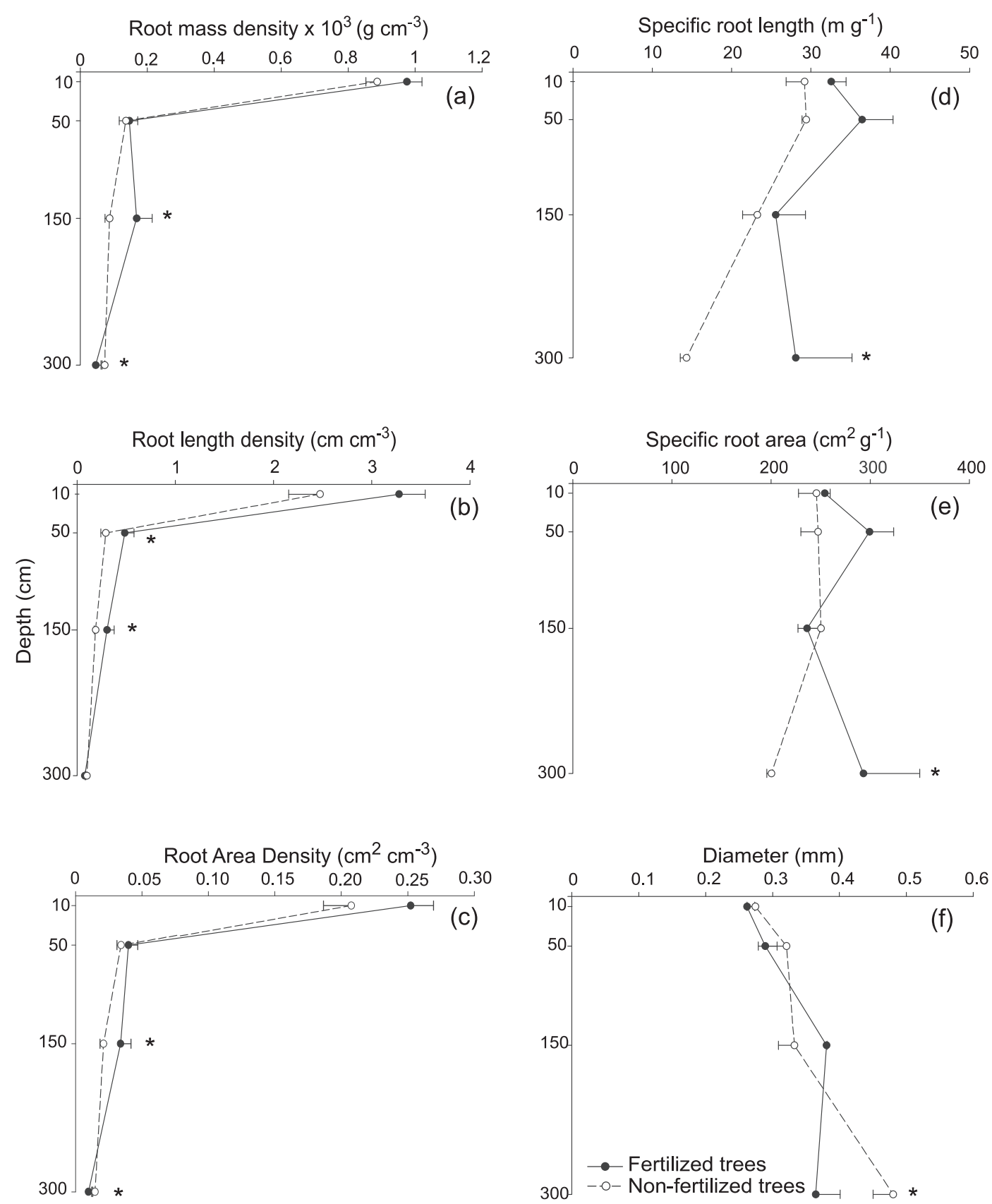

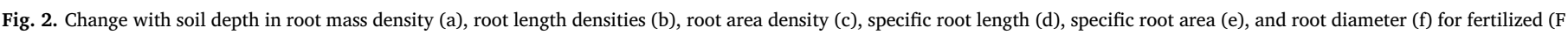

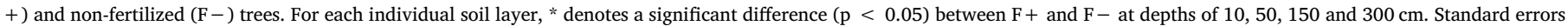
are indicated $(\mathrm{n}=12)$.

$270 \mathrm{~cm}^{2} \mathrm{~g}^{-1}$ in $\mathrm{F}+$ and $236 \mathrm{~cm}^{2} \mathrm{~g}^{-1}$ in $\mathrm{F}-$ with a significantly higher value for $\mathrm{F}+$ than for $\mathrm{F}-$ at a depth of $300 \mathrm{~cm}(\mathrm{~W}=-3.45$; $\mathrm{P}<0.001$ ) (Fig. 2e). A significant depth $\times$ fertilization interaction ( $D=9.48 ; \mathrm{P}<0.05$ ) was the result of lower SRA for $\mathrm{F}+$ than $\mathrm{F}-$ at a depth of $150 \mathrm{~cm}(\mathrm{~W}=-3.45 ; \mathrm{P}<0.001)$. Fine root diameter was significantly influenced by depth $(\mathrm{D}=44.65 ; \mathrm{P}<0.01)$. A general trend of increase in root diameter with depth was observed for both treatments with average values of $0.29 \mathrm{~mm}$ at $10-50 \mathrm{~cm}$ and $0.39 \mathrm{~mm}$ at $150-300 \mathrm{~cm}$ (Fig. 2f). There was no significant effect of fertilization on fine root diameter. However, the diameters were, on average, $0.36 \mathrm{~mm}$ in $\mathrm{F}+$ and $0.48 \mathrm{~mm}$ in $\mathrm{F}-$, with significantly higher value for $\mathrm{F}-$ at a depth of $300 \mathrm{~cm}$ than $\mathrm{F}+(\mathrm{W}=-4.24 ; \mathrm{P}<0.001)$. A significant depth $\times$ fertilization interaction $(\mathrm{D}=11.63$; $\mathrm{P}<0.01)$ was the result of lower diameter in $\mathrm{F}-$ at a depth of $150 \mathrm{~cm}(\mathrm{~W}=3.28$; $\mathrm{P}<0.001)$. Fine root tissue density was significantly influenced by depth
( $\mathrm{D}=26.294 ; \mathrm{P}<0.001)$ with decreasing values down to a depth of $300 \mathrm{~cm}$ for both treatments (Fig. 5). There was no significant global effect of fertilization. However, significant lower value for F + than Fat a depth of $300 \mathrm{~cm}$ was found. There was no significant interaction between depth and fertilization for fine root tissue density.

\subsection{Relative uptake potential of tracers}

The RUPs of $\mathrm{NO}_{3}{ }^{-}{ }^{-15} \mathrm{~N}$ were significantly influenced by the depth of tracer injection for both treatments: fertilized trees $(t=-5.18$; $\mathrm{P}<0.001)$ and non-fertilized trees $(\mathrm{t}=-8.35 ; \mathrm{P}<0.001)$. The RUPs of $\mathrm{NO}_{3}{ }^{-15} \mathrm{~N}$ was 16 times higher at a depth of $10 \mathrm{~cm}$ than $300 \mathrm{~cm}$ with mean values of $63 \%$ and $4 \%$, respectively (Fig. 3a). The distribution of RUPs of $\mathrm{NO}_{3}{ }^{-15} \mathrm{~N}$ along the soil profile was not significantly influenced by fertilization. The significant interaction depth $\mathrm{x}$ 
Relative uptake potential (\%)
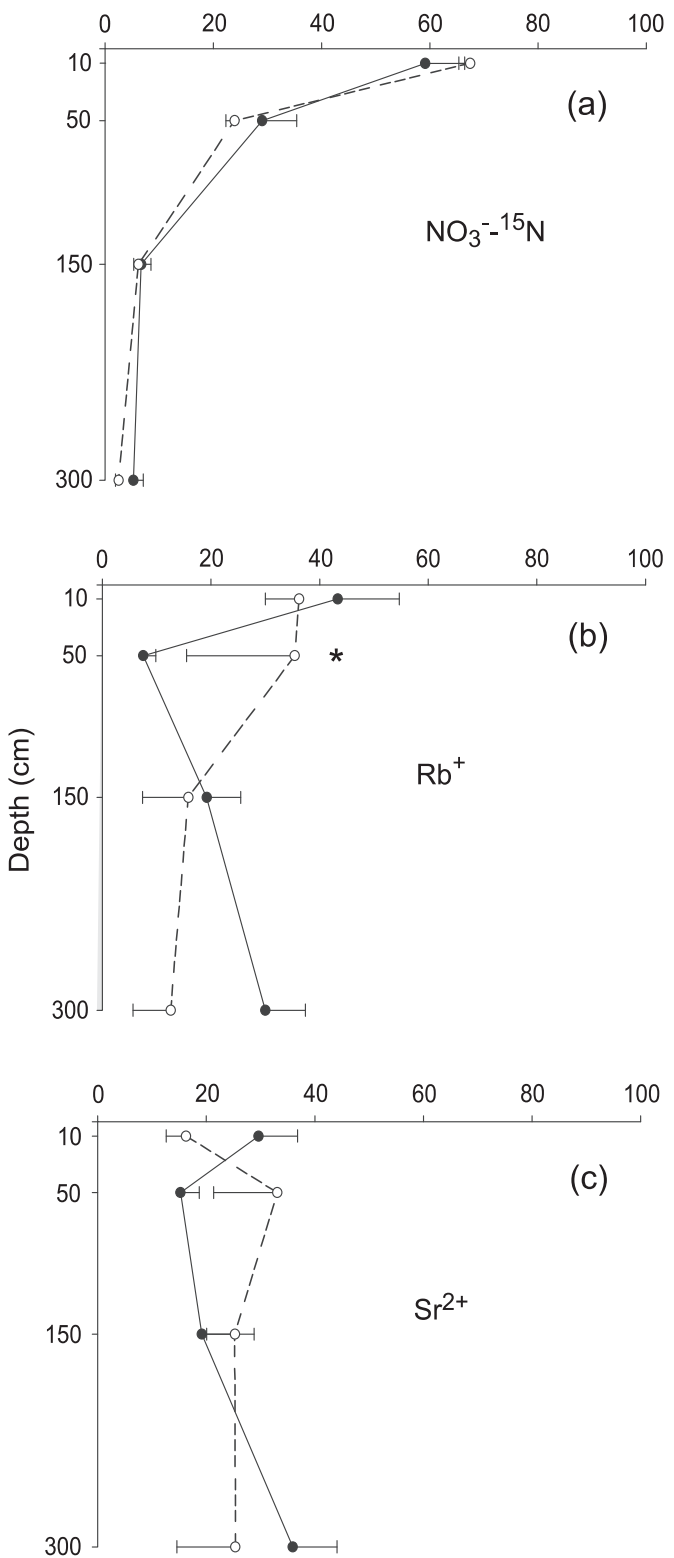

Specif relative uptake potential $\left(\% \mathrm{~cm}^{-1} \mathrm{~cm}^{3}\right)$
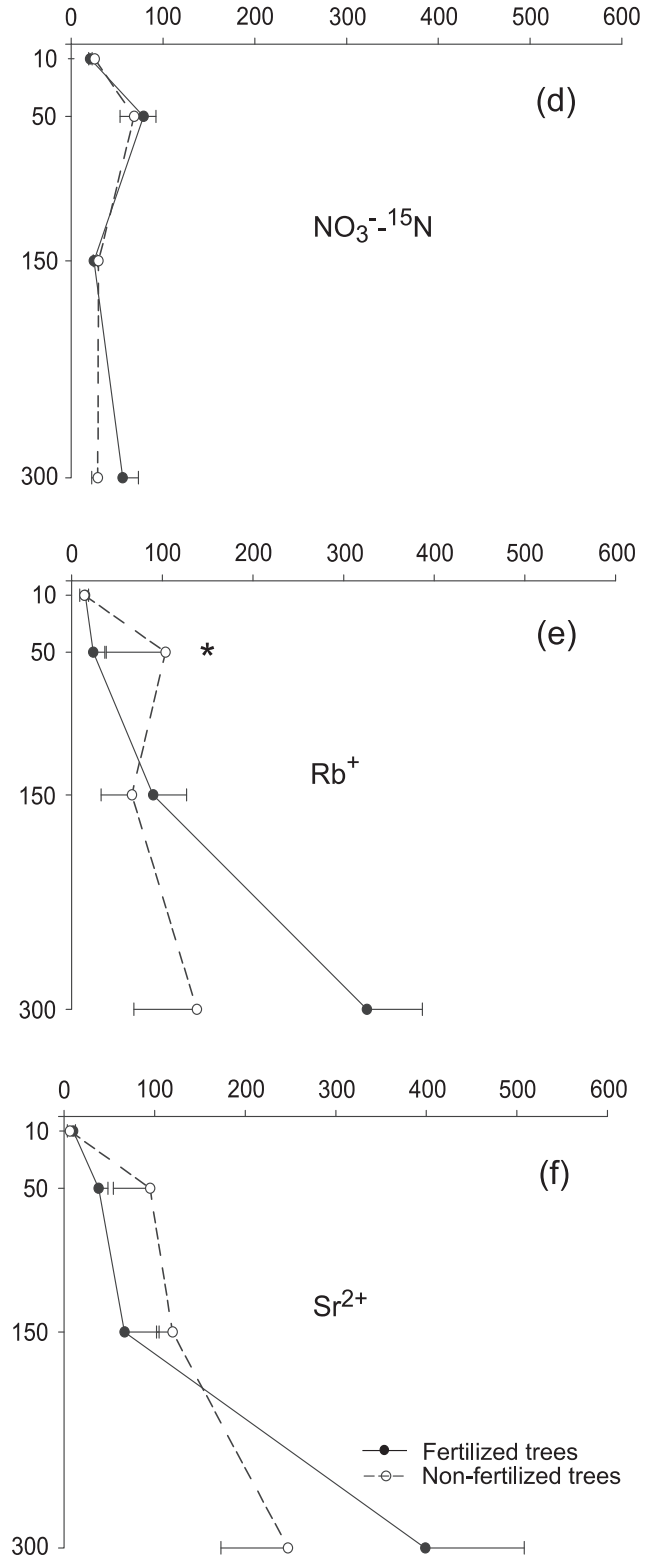

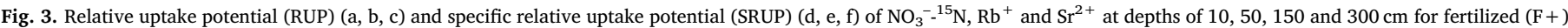

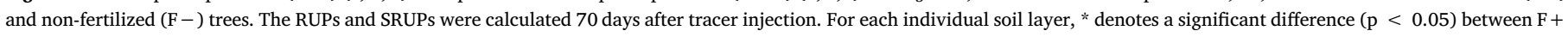
and F - at depths of 10, 50, 150 and $300 \mathrm{~cm}$. The effect of depth is only significant for SRUP of Rb + in $\mathrm{F}+$. Standard errors are indicated (n $=3$ ).

fertilization $(\mathrm{D}=5.28$; $\mathrm{P}<0.05)$ was the result of lower RUP for $\mathrm{F}+$ than $\mathrm{F}-$ at a depth of $10 \mathrm{~cm}$ with mean values of $59 \%$ and $67 \%$, respectively, the opposite being found at a depth of $300 \mathrm{~cm}$ with $5 \%$ and $2 \%$. The distributions of the RUPs of $\mathrm{Rb}^{+}$and $\mathrm{Sr}^{2+}$ along soil profile were uniforms (RUP values did not differ among soil layers) and not differ between fertilization treatments, with no significant interaction between the two factors. The RUP of Rb + was significantly higher at a depth of $50 \mathrm{~cm}$ for $\mathrm{F}+$ than $\mathrm{F}-(\mathrm{t}=2.35$; $\mathrm{P}<0.05)$ (Fig. 3b). However, the RUPs of $\mathrm{Rb}^{+}$and $\mathrm{Sr}^{2+}$ were higher at a depth of $300 \mathrm{~cm}$ in $\mathrm{F}+$ than in $\mathrm{F}$ - with mean values of $29 \%$ and $35 \%$ compared to 12 and $25 \%$, respectively (Fig. $3 \mathrm{~b}$ and $3 \mathrm{c}$ ). The RUP was significantly higher for $\mathrm{NO}_{3}{ }_{-}^{-15} \mathrm{~N}$ than $\mathrm{Sr}^{2+}$ at a depth of $10 \mathrm{~cm}$ in $\mathrm{F}-(\mathrm{W}=3.16 ; \mathrm{P}<0.01)$, with mean values of 67 and $16 \%$, respectively (Fig. 3a). The RUP of

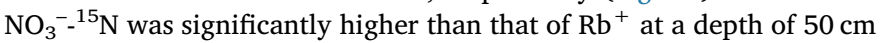
in $\mathrm{F}+(\mathrm{W}=3.41 ; \mathrm{P}<0.01)$. The RUP was significantly lower in $\mathrm{F}+$ and $\mathrm{F}-$ for $\mathrm{NO}_{3}{ }^{-}{ }^{15} \mathrm{~N}$ than $\mathrm{Rb}^{+}$at depths of $150 \mathrm{~cm}(\mathrm{~W}=-2.67$;
$\mathrm{P}<0.05$ and $\mathrm{W}=-2.22 ; \mathrm{P}<0.01$, respectively) and $300 \mathrm{~cm}$ $(\mathrm{W}=-4.42 ; \mathrm{P}<0.001$ and $\mathrm{W}=-3.78 ; \mathrm{P}<0.001$, respectively). The RUP was significantly lower in $\mathrm{F}+$ and $\mathrm{F}-$ for $\mathrm{NO}_{3}{ }_{-}^{-}{ }^{15} \mathrm{~N}$ than $\mathrm{Sr}^{2+}$ at depths of $150 \mathrm{~cm}(\mathrm{~W}=-2.8 ; \mathrm{P}<0.05$ and $\mathrm{W}=-3.13 ; \mathrm{P}<0.01$, respectively) and $300 \mathrm{~cm}(\mathrm{~W}=-4.87 ; \mathrm{P}<0.001$ and $\mathrm{W}=-4.02$; $\mathrm{P}<0.001$, respectively). The RUPs of $\mathrm{Rb}^{+}$and $\mathrm{Sr}^{2+}$ were not significantly different, whatever the depth of tracer injection.

\subsection{Specific relative uptake potential of tracers}

The distribution of SRUPs for $\mathrm{NO}_{3}{ }_{-}^{-}{ }^{15} \mathrm{~N}$ along the soil profile was uniform (SRUP values did not differ among soil layers) and was not affected by fertilization. However, the mean values of the SRUPs of $\mathrm{NO}_{3}{ }_{-}{ }^{15} \mathrm{~N}$ were $37 \%$ higher at $10-50 \mathrm{~cm}\left(48 \% \mathrm{~cm}^{-1} \mathrm{~cm}^{3}\right)$ than at $150-300 \mathrm{~cm}\left(35 \% \mathrm{~cm}^{-1} \mathrm{~cm}^{3}\right)$ (Fig. 3d). The SRUPs of $\mathrm{Rb}^{+}$were significantly influenced by depths in $\mathrm{F}+(\mathrm{t}=-4.29$; $\mathrm{P}<0.001)$ with 


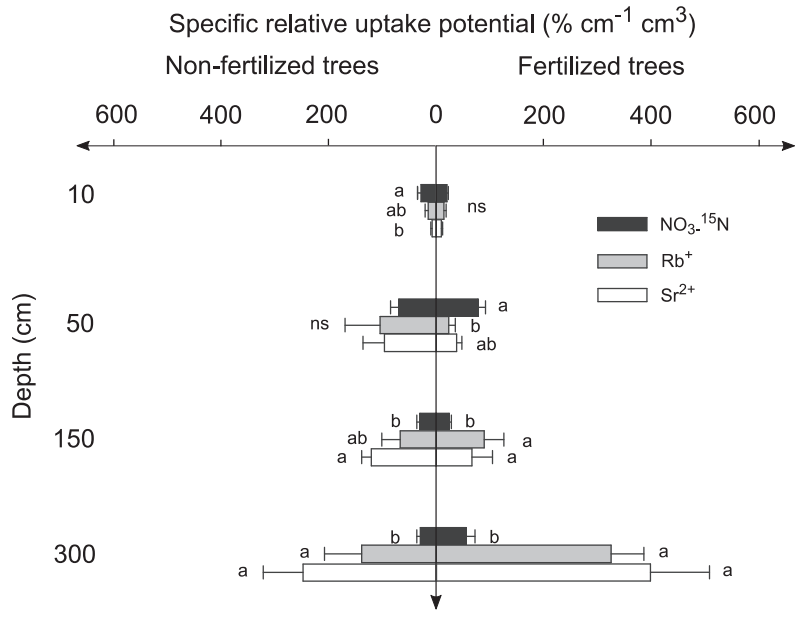

Fig. 4. Specific relative uptake potential (SRUP) of $\mathrm{NO}_{3}{ }^{-}{ }^{15} \mathrm{~N}, \mathrm{Rb}^{+}$and $\mathrm{Sr}^{2+}$ at depths of 10, 50, 150 and $300 \mathrm{~cm}$ for fertilized (right) and non-fertilized trees (left). The SRUPs were calculated from determinations in leaves sampled 70 days after tracer injection. Standard errors are indicated $(n=3)$. Different letters indicate significant differences between tracers in each soil layer for each treatment $(\mathrm{p}<0.05)$.

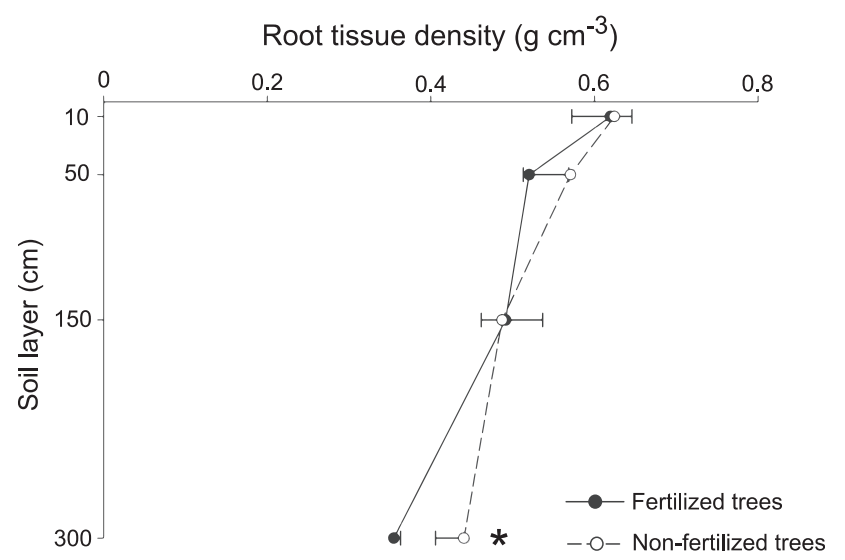

Fig. 5. Changes with depth in root tissue density for fertilized $(F+)$ and non-fertilized $(\mathrm{F}-)$ trees. For each individual soil layer, * denotes a significant difference $(\mathrm{p}<0.05)$ between $\mathrm{F}+$ and $\mathrm{F}-$. Standard errors are indicated $(\mathrm{n}=3)$.

increasing values in line with the application depth, but not in F(Fig. 3e). The mean values of the SRUPs of $\mathrm{Rb}^{+}$were $39 \% \mathrm{~cm}^{-1} \mathrm{~cm}^{3}$ at $10-50 \mathrm{~cm}$ and $155 \% \mathrm{~cm}^{-1} \mathrm{~cm}^{3}$ at $150-300 \mathrm{~cm}$ (Fig. 3e). The distribution of SRUPs along the soil profile for $\mathrm{Rb}^{+}$were marginally influenced by fertilization ( $\mathrm{D}=3.18$; $\mathrm{P}<0.07$ ). The marginally significant depth $\mathrm{x}$ fertilization interaction for $\mathrm{Rb}^{+}$was mainly a result of a lower SRUP at a depth of $50 \mathrm{~cm}$ in $\mathrm{F}+\left(24 \% \mathrm{~cm}^{-1} \mathrm{~cm}^{3}\right)$ than in $\mathrm{F}-$ $\left(103 \% \mathrm{~cm}^{-1} \mathrm{~cm}^{3}\right)$, the opposite being found at a depth of $300 \mathrm{~cm}$ with mean values of 325 and $138 \% \mathrm{~cm}^{-1} \mathrm{~cm}^{3}$, respectively. The SRUPs of $\mathrm{Rb}^{+}$was significantly higher at a depth of $50 \mathrm{~cm}$ for $\mathrm{F}+$ than $\mathrm{F}-$ $(\mathrm{t}=3 ; \mathrm{P}<0.05)$. The SRUPs of $\mathrm{Sr}^{2+}$ were significantly influenced by injection depth both for fertilized trees $(\mathrm{t}=-5.32$; $\mathrm{P}<0.001)$ and non-fertilized trees $(\mathrm{t}=-3.46 ; \mathrm{P}<0.001)$, but not by fertilization. The mean values of the SRUPs of $\mathrm{Sr}^{2+}$ values were $37 \% \mathrm{~cm}^{-1} \mathrm{~cm}^{3}$ at $10-50 \mathrm{~cm}$ and $208 \% \mathrm{~cm}^{-1} \mathrm{~cm}^{3}$ at $150-300 \mathrm{~cm}$ (Fig. 3f). There was no significant depth $\mathrm{x}$ fertilization interaction. However, the SRUPs values of $\mathrm{Sr}^{2+}$ at a depth of $50 \mathrm{~cm}$ was lower in $\mathrm{F}+\left(38 \% \mathrm{~cm}^{-1} \mathrm{~cm}^{3}\right)$ than in $\mathrm{F}-\left(95 \% \mathrm{~cm}^{-1} \mathrm{~cm}^{3}\right)$, the opposite being found at $300 \mathrm{~cm}$ depth with mean values of 398 and $247 \% \mathrm{~cm}^{-1} \mathrm{~cm}^{3}$, respectively. The SRUP of $\mathrm{NO}_{3}{ }^{-1}{ }^{15} \mathrm{~N}$ was significantly higher than the SRUP of $\mathrm{Sr}^{2+}$ at a depth of $10 \mathrm{~cm}$ in $\mathrm{F}-(\mathrm{W}=2.53 ; \mathrm{P}<0.05)$ and higher than the SRUP of $\mathrm{Rb}^{+}$ at a depth of $50 \mathrm{~cm}$ in $\mathrm{F}+(\mathrm{W}=2.69 ; \mathrm{P}<0.05)$ (Fig. 4). The SRUP of $\mathrm{Rb}^{+}$was significantly higher than the SRUP of $\mathrm{NO}_{3}{ }^{-}{ }^{-15} \mathrm{~N}$ at depths of
$150 \mathrm{~cm}(\mathrm{~W}=-2.93 ; \mathrm{P}<0.01)$ and $300 \mathrm{~cm}(\mathrm{~W}=-3.99 ; \mathrm{P}<0.001)$ in $\mathrm{F}+$ and of $300 \mathrm{~cm}$ in $\mathrm{F}-(\mathrm{W}=-2.94 ; \mathrm{P}<0.01)$ (Fig. 4). The SRUP of $\mathrm{Sr}^{2+}$ was significantly higher than $\mathrm{NO}_{3}{ }^{-}{ }^{-15} \mathrm{~N}$ in $\mathrm{F}+$ and $\mathrm{F}-$ at depths of $150 \mathrm{~cm}(\mathrm{~W}=-2.29 ; \mathrm{P}<0.05$ and $\mathrm{W}=-2.61 ; \mathrm{P}<0.05$, respectively) and $300 \mathrm{~cm}(\mathrm{~W}=-4.45 ; \mathrm{P}<0.001$ and $\mathrm{W}=-4.02$; $\mathrm{P}<0.001$, respectively) (Fig. 4). The SRUPs of $\mathrm{Rb}^{+}$and $\mathrm{Sr}^{2+}$ were not significantly different, whatever the depth of tracer injection.

\section{Discussion}

\subsection{Potential methodological limitations}

Our assessment of the nutrient uptake capacity of tree roots in situ is associated with non-negligible methodological limitations, as stressed in previous studies (da Silva et al., 2011, 2008). Tracer availability for tree roots may have differed depending on depth and element properties. $\mathrm{N}$ microbial immobilization increases with soil organic resources (He et al., 2016) and $\mathrm{NO}_{3}{ }^{-}$may be preferentially bound in surface soils with higher organic matter content than in deep soil layer (Barrett and Burke, 2000). Moreover, $\mathrm{N}$ concentrations in soil solutions and turnover rates are likely to be higher in the topsoil than in deep soil layers (Voigtlaender et al., 2012). As a result, $\mathrm{NO}_{3}{ }^{-15} \mathrm{~N}$ concentrations in soil solutions could have been lower in the topsoil than in deep soil layers. However, the dynamics of nutrient concentrations (in particular nitrate) monitored from planting to harvesting at different depths in Eucalyptus plantations at our study site showed that large amounts of nitrate in the topsoil move downwards in the soil profile (Maquère, 2008; Laclau et al., 2010). Large amounts of rainfall in this soil with a high sand content make unlikely a strong immobilization of ${ }^{15} \mathrm{~N}$ in the top soil. In another study carried out in eucalypt plantations in Congo, Versini et al. (2014) showed that ${ }^{15} \mathrm{~N}$-labelled harvest residues led to a clear increase in ${ }^{15} \mathrm{~N}$ in soil solutions sampled at the depths of $50 \mathrm{~cm}$ and $100 \mathrm{~cm}$, which confirms the mobility of nitrate produced in the

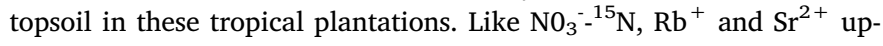
take rates were not compensated for differences in their dilution in the soil or their sorption to soil particles depending on depth. Roots and mycorrhiza nutrient uptake zone may be overlapping more in the topsoil than in deep soil layers, which is another limitation of our approach that could contribute to increasing the SRUP of $\mathrm{Rb}^{+}$and $\mathrm{Sr}^{2+}$ with soil depth (Göransson et al., 2006, 2008). The SRUPs were significantly higher at a depth of $300 \mathrm{~cm}$ than at a depth of $10 \mathrm{~cm}$ for $\mathrm{Rb}^{+}$ and $\mathrm{Sr}^{2+}$, whereas the SRUP was not influenced by soil depth for the $\mathrm{NO}_{3}{ }_{-}^{-15} \mathrm{~N}$ tracer applied simultaneously at the same positions. This pattern for the mobile $\mathrm{NO}_{3}{ }^{-}$suggests that an overlap of the uptake zones around roots in the topsoil was unlikely to explain the large increase in the SRUP with soil depth observed for the analogues of $\mathrm{K}^{+}$and $\mathrm{Ca}^{2+}$. Differences in the RLD between depths might have biased the estimation of the SRUP because tracers were added at a higher proportion for a given root length at depth than in the surface soil layers. Such bias should have been more pronounced for the highly mobile tracer $\mathrm{NO}_{3}{ }_{-}^{-15} \mathrm{~N}$ than for $\mathrm{Rb}^{+}$and $\mathrm{Sr}^{2+}$. Moreover, SRUP was calculated as the ratio between RUP and fine root length per unit of soil volume with mean RLD estimated at each injection depth (in a soil layer of thickness $20 \mathrm{~cm}$ at injections depths 10 and $50 \mathrm{~cm}$ depth, and of thickness $40 \mathrm{~cm}$ at injection depths 150 and $300 \mathrm{~cm}$ ). However, the actual volume of soil in which trees take up nutrients is not exactly the soil layer where RLDs were measured, which could slightly modify SRUPs values. A bioassay comparing E. grandis roots sampled at different depths would be useful in future studies to check the effect of depth on the element uptake capacity, as shown by Göransson et al. (2007) for excised roots of $Q$. robur.

A recent study found ectomycorrhizae associated with roots to $4 \mathrm{~m}$ depth in a nearby $E$. grandis stand (unpublished data) suggesting the need to gain insights into the role of mycorrhizal association in fine root functional specialization. Here, ectomycorrhizal root tips were also observed down to $3 \mathrm{~m}$ (data not shown). High ectomycorrhizal 
colonization was found in both $\mathrm{F}+$ and $\mathrm{F}-$ at $10 \mathrm{~cm}$ and $50 \mathrm{~cm}$ depth and could partly explain the comparable SRUP of $\mathrm{NO}_{3}{ }^{-}{ }^{-15} \mathrm{~N}$ for fertilized and non-fertilized trees in the topsoil. A black morphotype (probably involving Thelephora sp. or Tomentella sp. fungi) was observed only in the upper layers while a yellow morphotype (probably involving Pisolithus $s p$. fungi) was found along the whole soil profile. The diversity of morphotypes between surface and deep soil layers might contribute to explaining the differences in functional fine root specialization. Despite these potential limitations, the marked differences in relative uptake rates between tracers for a given depth, between depths for a given tracer, and between treatments were unlikely to lead to erroneous conclusions on the fine root specialization of $E$. grandis at young stand stage depending on fertilization.

\subsection{Fine roots functional specialization at young tree age}

The results are in agreement with our first hypothesis of a functional specialization of fine roots for young $E$. grandis trees depending on soil depth, as previously observed for 6-year-old E. grandis trees in the same region (da Silva et al., 2011). The uptake of tracers by $E$. grandis trees down to $3 \mathrm{~m}$ deep at 20 months of age is consistent with the rapid soil exploration of fine roots that can reach a depth of 13 meters at 18 months of age in deep Ferralsols (Pinheiro et al., 2016). The sharp decrease in RMD and RLD with depth, as observed in other Eucalyptus plantations irrespective of trees age (Christina et al., 2011; Pinheiro et al., 2016), is consistent with the decrease with depth of the RUPs of $\mathrm{NO}_{3}{ }^{-}$shown for mature $E$. grandis trees (da Silva et al., 2011) and for other tropical tree species (Gathumbi et al., 2003; Soethe et al., 2006). Nitrate absorption was higher when RMD increased and this result would be consistent with regular nitrate absorption along the root as shown for Pinus pinaster (Plassard et al., 2002). However, the RUPs of $\mathrm{Rb}^{+}$and $\mathrm{Sr}^{2+}$ were not significantly affected by the injection depth, contrary to the observations of da Silva et al. (2011) at the harvesting age. This pattern suggests a marked specialization of deep Eucalyptus fine roots for uptake of the analogues of $\mathrm{K}^{+}$and $\mathrm{Ca}^{2+}$ at the beginning of stand rotation.

The SRUP distributions of $\mathrm{Rb}^{+}$and $\mathrm{Sr}^{2+}$ met the hypothesis of functional specialization of fine roots with significantly higher values at $300 \mathrm{~cm}$ depth than at 10 and $50 \mathrm{~cm}$ depths for both tracers. The higher SRUPs of $\mathrm{Rb}^{+}$and $\mathrm{Sr}^{2+}$ in deep soil layers than in the topsoil are consistent with higher fine root diameters, which might make it possible to increase the capacity of nutrient absorption through root cortex and associated mycorrhizas and transport capacity in root stele (Guo et al., 2008; Kong et al., 2017). Wang et al. (2015) showed that the diameter of first-order roots of 3 temperate hardwood species increased with depth and presented differences in xylem structure. Deep roots had thicker stele, wider maximum conduit and greater number of conduits per stele than shallow roots. These characteristics led to higher theoretical hydraulic conductivity of deep roots increasing their efficiency of water and nutrient transportation. Increase in fine root diameter with soil depth was also reported in other studies (e.g. Fort et al., 2017). The decrease in fine root tissue density (RTD) with soil depth might also lead to higher root specific hydraulic conductivity, as found for Australian tree and shrub species (Pate et al., 1995). Higher root specific hydraulic conductivities might increase the mass flow from the soil to the roots and then increase nutrient root uptake in deep soil layers relative to the topsoil (Costa et al., 2017). This pattern would be also consistent with larger diameters of xylem vessels in deep fine roots than in shallow fine roots observed in a nearby $E$. grandis stand (unpublished data), and in other studies (McElrone et al., 2004). The mean values of SRUP of $\mathrm{Rb}^{+}$and $\mathrm{Sr}^{2+}$ at $300 \mathrm{~cm}$ depth in the 20 -month-old trees sampled here were $40 \%$ higher than in 63-month-old trees in the same soil type (sandy soil) with tracer injection at the same season (da Silva et al., 2011). This result suggests a greater specialization of deep fine roots to take up $\mathrm{Rb}^{+}$and $\mathrm{Sr}^{2+}$ over the early growth of eucalypt trees when nutrient requirements are higher than at the end of stand rotation
(Laclau et al., 2010).

A specialization of fine roots in $\mathrm{NO}_{3}{ }^{-}{ }_{-}^{15} \mathrm{~N}$ uptake was also likely with higher SRUPs within the topsoil layers rather than at great depth. However, the mean values of SRUP for $\mathrm{Rb}^{+}$and $\mathrm{Sr}^{2+}$ at $300 \mathrm{~cm}$ depth (231 and $323 \% \mathrm{~cm}^{-1} \mathrm{~cm}^{3}$, respectively) were 4.8 and 6.8 times higher than that of SRUP of $\mathrm{NO}_{3}{ }^{-}$at $10-50 \mathrm{~cm}\left(48 \% \mathrm{~cm}^{-1} \mathrm{~cm}^{3}\right)$, suggesting higher fine root specialization in the uptake of $\mathrm{Rb}^{+}$and $\mathrm{Sr}^{2+}$ in deep soil layers than of $\mathrm{NO}_{3}{ }^{-}{ }^{15} \mathrm{~N}$ in surface soil. This pattern could be also partly explained by the changes in fine root density distributions with tree age. RLDs were twice as high at 20 months of age in the surface layers as at 63 months (da Silva et al., 2011), whereas they were similar at $300 \mathrm{~cm}$ depth. The mean value of SRUP of $\mathrm{NO}_{3}{ }_{-}^{-15} \mathrm{~N}$ at $10-50 \mathrm{~cm}$ was $48 \% \mathrm{~cm}^{-1} \mathrm{~cm}^{3}$ in our study and $69 \% \mathrm{~cm}^{-1} \mathrm{~cm}^{3}$ at the end of stand rotation for the same season of tracer injection (da Silva et al., 2011). $\mathrm{NO}_{3}{ }^{-}$uptake probably does not change proportionally to RLD for high RLDs in the topsoil due to overlapping depletion zones (Andrews and Newman, 1970). The lower specialization of fine roots for $\mathrm{NO}_{3}{ }^{-}$uptake in the topsoil than in depth for $\mathrm{Rb}^{+}$and $\mathrm{Sr}^{2+}$ could be also related to $\mathrm{pH}$ variations along the soil profile. Garnett and Smethurst (1999) showed that low $\mathrm{pH}$ led to higher $\mathrm{NH}_{4}{ }^{+}$uptake of Eucalyptus nitens Maiden fine roots $(200 \%$ higher at $\mathrm{pH}=4$ than at $\mathrm{pH}=6)$ but $\mathrm{pH}$ did not influence nitrate uptake. Here, $\mathrm{pH}$ values increased with depth (Table 1) as observed by Pradier et al. (2016) in a nearby eucalypt plantation. This higher potentiality of $\mathrm{NH}_{4}{ }^{+}$uptake in the surface soil layers than in depth might then result in lowering $\mathrm{NO}_{3}{ }^{-}$uptake at $10-50 \mathrm{~cm}$ deep. The effect of depth on SRUP for a given tracer and the differences between tracers for a given depth in our study were marked and consistent for fertilized and non-fertilized trees. These results strongly support the hypothesis of functional specialization of fine roots for young eucalypt trees.

\subsection{Fertilization enhances fine roots functional specialization}

Fertilization at planting led to higher values of RMD, RLD and RAD along the soil profile for fertilized than for non-fertilized trees, except at a depth of $3 \mathrm{~m}$. Applying fertilization at planting in Eucalyptus plantations established in sandy soil increases nutrient concentrations in soil solutions down to a depth of $3 \mathrm{~m}$ over the first 2 years after planting (Laclau et al., 2002, 2010; Silva et al., 2013). The changes in fine roots biomass with soil fertility are still controversial (Nadelhoffer, 2000). Most of studies reported a decrease in fine root biomass when soil fertility increases (Aber et al., 1985; Coomes and Grubb, 2000; Nadelhoffer, 2000; Vanninen and Makela, 1999; Yuan and Chen, 2010). However, no effect (Leuschner et al., 2004) or higher fine root biomass (George et al., 1997) were also observed when soil fertility increases, and there were greater mean RLD in high than low productive $E$. grandis stands close to the experimental area (Maurice et al., 2010). The differences between $\mathrm{F}+$ and $\mathrm{F}-$ in RUPs of $\mathrm{Rb}^{+}$and $\mathrm{Sr}^{2+}$ did not mirror the changes in RMD, RLD and RAD in deep soil layers. At a depth of $300 \mathrm{~cm}, \mathrm{RMD}$ and RAD values were lower for fertilized than for nonfertilized trees. However, at a depth of $300 \mathrm{~cm} \mathrm{RUPs} \mathrm{of} \mathrm{Rb}^{+}$and $\mathrm{Sr}^{2+}$ were $140 \%$ and $40 \%$ higher for $\mathrm{F}+$ than for $\mathrm{F}-$, which suggests a higher ability of fine roots of fertilized trees to take up these two tracers. The higher RUPs in F + than in F- could also be a result of higher mass flow to the roots due to higher transpiration of fertilized trees than non-fertilized trees (Hubbard et al., 2004; Battie-Laclau et al., 2016).

Consistent with our second hypothesis, the SRUPs of $\mathrm{Rb}^{+}$and $\mathrm{Sr}^{2+}$ are on average 136 and $61 \%$ higher in $\mathrm{F}+$ than in $\mathrm{F}-$ at a depth of $300 \mathrm{~cm}$, respectively, showing that fertilization likely increases the capacity of deep fine roots to take up $\mathrm{K}^{+}$and $\mathrm{Ca}^{2+}$ analogues. Significant lower RTD in F + than F - in depth may lead to higher root specific hydraulic conductivity for fertilized trees and therefore to higher $\mathrm{Rb}^{+}$and $\mathrm{Sr}^{2+}$ uptake by unit of root length. This characteristic counterbalances the potential lower hydraulic conductivity resulting from lower root diameter at a depth of $3 \mathrm{~m}$ in $\mathrm{F}+$ than in $\mathrm{F}-$.

SRUP of $\mathrm{Sr}^{2+}$ at $3 \mathrm{~m}$ depth was also enhanced by NPK and 
micronutrient addition, while calcium availability is not limiting the early growth of Eucalyptus trees in the study region, in contrast to $\mathrm{N}$ and K (Gonçalves et al., 2013). Therefore, improving the general nutrient status of Eucalyptus trees may affect several mechanisms of nutrient acquisition. Root specific hydraulic conductivity of $E$. grandis growing in pots was greater with high-localised availability of $\mathrm{P}$ than low $\mathrm{P}$ supply, leading to higher water and nutrients uptake (Costa et al., 2017). A study on the expression levels of nitrate and phosphate transporters genes in A. thaliana brought out evidences of a crosstalk between $\mathrm{N}$ and $\mathrm{P}$ transporters in regulating root nutrient uptake: e.g. AtPHT1;2, a major Pi transporter, was suppressed by nitrate starvation and induced by nitrate resupply (Bao et al., 2011). Rowe et al. (2008) showed that tissue $\mathrm{P}$ and $\mathrm{K}$ concentrations of Calluna vulgaris increased across a $\mathrm{N}$ deposition gradient, showing that acquisition of other plant nutrients was limited by $\mathrm{N}$. The authors put forward the hypothesis that elevated $\mathrm{P}$ and $\mathrm{K}$ concentrations possibly resulted from improved acquisition due to additional root enzyme production or mycorrhizal activity (Rowe et al., 2008).

\section{Conclusions and perspectives}

Contrasting E. grandis potential uptake rates of $\mathrm{NO}_{3}{ }^{-1}{ }^{15} \mathrm{~N}, \mathrm{Rb}^{+}$and $\mathrm{Sr}^{2+}$ with depth at 2 years of age are consistent with previous results at harvesting age (da Silva et al., 2011). Functional root specialization increases with fertilization at planting time that likely improves potassium and calcium uptake in deep soil layers and contributes to very low amounts of cations lost by deep drainage in Eucalyptus plantations, even in highly fertilized stands (Laclau et al., 2010). Our findings reinforce the suggestion of these authors to apply fertilization once at planting for Eucalyptus stands established on deep soils with unhindered root development.

Further studies must be conducted to gain insights into the processes of fine root specialization. Mycorrhizal fungi that increase plant acquisition of N (Gobert and Plassard, 2008; Mayor et al., 2015), K and Ca (Garcia and Zimmermann, 2014; Jourand et al., 2014) could potentially impact the nutrient uptake of fine roots in depth. Fertilization could lead to change in microbial communities in depth, and then potentially to influence fine root specialization (Li et al., 2014; Gu et al., 2017). Variation of root hairs depending on depth and fertilization should also be an important process of functional fine root specialization of Eucalyptus trees, as root hair cells are highly selective for $\mathrm{K}$ (Maathuis and Sanders, 1996) and root hair elongation can increase with K concentrations within plants (Dolan, 2001). Getting insights into the potential uptake rate of $\mathrm{P}$ with soil depth would also be interesting to get a more global picture on fine roots specialization of Eucalyptus trees. Such studies could be conducted on Eucalyptus plants in controlled conditions using ${ }^{32} \mathrm{P}$ or ${ }^{33} \mathrm{P}$ tracers (Lehmann, 2003) or on excised roots (Göransson et al., 2007).

\section{Acknowledgments}

We are grateful for the support of the SOERE F-ORE-T (granted by Ecofor, Allenvi and the French National Research Infrastructure ANAEEF (http://www.anaee-france.fr/fr/), FAPESP Thematic Project (2010/16623-9) and Intens\&fix Project (ANR-2010-STRA-004-03). We gratefully acknowledge Rildo M. Moreira and the staff of Itatinga Research Station (ESALQ/USP) as well as Eder Araujo da Silva (http:// www.floragroapoio.com.br) and Dr Laurent Saint André (INRA UR $1138 \mathrm{BEF}$ ) for their technical support.

\section{Appendix A. Supplementary material}

Supplementary data associated with this article can be found, in the online version, at http://dx.doi.org/10.1016/j.foreco.2018.03.018.

\section{References}

Aber, J.D., Melillo, J.M., Nadelhoffer, K.J., Meclaugherty, C.A., Pastor, J., 1985. Fine root turnover in forest ecosystems in relation to quantity and form of nitrogen availability: a comparison of two methods. Oecologia 66, 317-321. http://dx.doi.org/10.1007/ BF00378292.

Al Afas, N., Marron, N., Zavalloni, C., Ceulemans, R., 2008. Growth and production of a short-rotation coppice culture of poplar-IV: fine root characteristics of five poplar clones. Biomass Bioenergy 32, 494-502. http://dx.doi.org/10.1016/j.biombioe. 2007.11.007.

Andrews, R.E., Newman, E.I., 1970. Root density and competition for nutrients. Oecologia Plantarum 5, 319-334 19711903163.

Bao, S., An, L., Su, S., Zhou, Z., Gan, Y., 2011. Expression patterns of nitrate, phosphate, and sulfate transporters in Arabidopsis roots exposed to different nutritional regimes. Botany 89, 647-653. http://dx.doi.org/10.1139/b11-053.

Barrett, J.E., Burke, I.C., 2000. Potential nitrogen immobilization in grassland soils across a soil organic matter gradient. Soil Biol. Biochem. 32, 1707-1716. http://dx.doi.org/ 10.1016/S0038-0717(00)00089-4.

Battie-Laclau, P., Delgado-Rojas, J.S., Christina, M., Nouvellon, Y., Bouillet, J.-P., Piccolo, M.C., Moreira, M.Z., Gonçalves, J.L.M., Roupsard, O., Laclau, J.-P., 2016. Potassium fertilization increases water-use efficiency for stem biomass production without affecting intrinsic water-use efficiency in Eucalyptus grandis plantations. Forest Ecol. Manage. 364, 77-89. http://dx.doi.org/10.1016/j.foreco.2016.01.004.

Binkley, D., 2015. Ecosystems in four dimensions. New Phytologist 206, 883-885. http:// dx.doi.org/10.1111/nph.13379.

Binkley, D., Campoe, O.C., Alvares, C., Carneiro, R.L., Cegatta, Í., Stape, J.L., 2017. The interactions of climate, spacing and genetics on clonal Eucalyptus plantations across Brazil and Uruguay. Forest Ecol. Manage. 405, 271-283. http://dx.doi.org/10.1016/ j.foreco.2017.09.050.

Booth, T.H., 2013. Eucalypt plantations and climate change. Forest Ecol. Manage. 301, 28-34. http://dx.doi.org/10.1016/j.foreco.2012.04.004.

Brassard, B.W., Chen, H.Y.H., Bergeron, Y., 2009. Influence of environmental variability on root dynamics in northern forests. Crit. Rev. Plant Sci. 28, 179-197. http://dx.doi. org $/ 10.1080 / 07352680902776572$.

Broedel, E., Tomasella, J., Cândido, L.A., von Randow, C., 2017. Deep soil water dynamics in an undisturbed primary forest in central Amazonia: differences between normal years and the 2005 drought. Hydrol. Processes 31, 1749-1759. http://dx.doi. org /10.1002/hyp. 11143.

Brunelle, T., Dumas, P., Souty, F., Dorin, B., Nadaud, F., 2015. Evaluating the impact of rising fertilizer prices on crop yields. Agric. Econom. (United Kingdom) 46, 653-666. http://dx.doi.org/10.1111/agec.12161.

Chapman, N., Miller, A.J., Lindsey, K., Whalley, W.R., 2012. Roots, water, and nutrient acquisition: Let's get physical. Trends Plant Sci. 17, 701-710. http://dx.doi.org/10. 1016/j.tplants.2012.08.001.

Christina, M., Laclau, J.P., Goncalves, J.L.M., Jourdan, C., Nouvellon, Y., Bouillet, J.P., 2011. Almost symmetrical vertical growth rates above and below ground in one of the world's most productive forests. Ecosphere. http://dx.doi.org/10.1890/ES1000158.1.

Christina, M., Nouvellon, Y., Laclau, J.-P., Stape, J.L., Bouillet, J.-P., Lambais, G.R., le Maire, G., 2017. Importance of deep water uptake in tropical eucalypt forest. Funct. Ecol. 31, 509-519. http://dx.doi.org/10.1111/1365-2435.12727.

Coomes, D.A., Grubb, P.J., 2000. Impacts of root competition in forests and woodlands: a theoretical framework and review of experiments. Ecol. Monographs 70, 171-207. http://dx.doi.org/10.1890/0012-9615(2000) 070[0171:IORCIF]2.0.CO;2.

Cornelissen, J.H.C.A., Lavorel, S.B., Garnier, E.B., Díaz, S.C., Buchmann, N.D., Gurvich, D.E.C., Reich, P.B.E., Steege, H.F., Morgan, H.D., Van Der Heijden, M.G.A., Pausas, J.G.H., Poorter, H.I., 2003. A handbook of protocols for standardised and easy measurement of plant functional traits worldwide. Aust. J. Botany 51, 335-380 0067 1924/03/040335.

Costa, L., Faustino, L.I., Graciano, C., 2017. The spatial distribution of phosphate in the root system modulates $\mathrm{N}$ metabolism and growth in Eucalyptus grandis young plants. Trees 31, 247-257. http://dx.doi.org/10.1007/s00468-016-1480-8.

Dolan, L., 2001. How and where to build a root hair. Curr. Opinion Plant Biol. 4, 550-554. http://dx.doi.org/10.1016/S1369-5266(00)00214-4.

da Silva, E.V., Bouillet, J.-P., de Moraes Gonçalves, J.L., Junior, C.H.A., Trivelin, P.C.O., Hinsinger, P., Jourdan, C., Nouvellon, Y., Stape, J.L., Laclau, J.-P., 2011. Functional specialization of Eucalyptus fine roots: contrasting potential uptake rates for nitrogen, potassium and calcium tracers at varying soil depths. Funct. Ecol. 25, 996-1006. http://dx.doi.org/10.1111/j.1365-2435.2011.01867.x.

Fan, Y., Miguez-Macho, G., Jobbágy, E.G., Jackson, R.B., Otero-Casal, C., 2017. Hydrologic regulation of plant rooting depth. Proc. Natl. Acad. Sci. USA 114 (40), 10572-10577.

FAO, 2014. World Reference Base for Soil Resources 2014. Italy, Rome.

FAO, 2015. Global Forest Resources Assessment 2015.

Freschet, G.T., Valverde-Barrantes, O.J., Tucker, C.M., Craine, J.M., Mccormack, M.L., Violle, C., Fort, F., Blackwood, C.B., Urban-Mead, K.R., Iversen, C.M., Bonis, A., Comas, L.H., Cornelissen, J.H.C., Dong, M., Guo, D., Hobbie, S.E., Holdaway, R.J., Kembel, S.W., Makita, N., Onipchenko, V.G., Picon-Cochard, C., Reich, P.B., de la Riva, E.G., Smith, S.W., Soudzilovskaia, N.A., Tjoelker, M.G., Wardle, D.A., Roumet, C., 2017. Climate, soil and plant functional types as drivers of global fine-root trait variation. J. Ecol. 105, 1182-1196. http://dx.doi.org/10.1111/1365-2745.12769.

Fort, F., Volaire, F., Guilioni, L., Barkaoui, K., Navas, M.-L., Roumet, C., 2017. Root traits are related to plant water-use among rangeland Mediterranean species. Funct. Ecol. 31, 1700-1709. http://dx.doi.org/10.1111/1365-2435.12888.

Garcia, K., Zimmermann, S.D., 2014. The role of mycorrhizal associations in plant 
potassium nutrition. Front. Plant Sci. 5, 1-9. http://dx.doi.org/10.3389/fpls.2014. 00337.

Garnett, T., Smethurst, P., 1999. Ammonium and nitrate uptake by Eucalyptus nitens: effects of $\mathrm{pH}$ and temperature. Plant Soil 214, 133-140. http://dx.doi.org/10.1023/ a:1004740204876.

Gathumbi, S.M., Cadisch, G., Buresh, R.J., Giller, K.E., 2003. Subsoil nitrogen capture in mixed legume stands as assessed by deep nitrogen-15 placement. Soil Sci. Soc. Am. J. 67, 573-582. http://dx.doi.org/10.2136/sssaj2003.0573.

George, E., Seith, B., Schaeffer, C., Marschner, H., 1997. Responses of Picea, Pinus and Pseudotsuga roots to heterogeneous nutrient distribution in soil. Tree Physiol. 17, 39-45. http://dx.doi.org/10.1093/treephys/17.1.39.

Germon, A., Guerrini, I.A., Bordron, B., Bouillet, J.-P., Nouvellon, Y., de Moraes Gonçalves, J.L., Jourdan, C., Paula, R.R., Laclau, J.-P., 2017. Consequences of mixing Acacia mangium and Eucalyptus grandis trees on soil exploration by fine-roots down to a depth of $17 \mathrm{~m}$. Plant and Soil, pp. 1-18. doi: 10.1007/s11104-017-3428-1.

Gobert, A., Plassard, C., 2008. The Beneficial Effect of Mycorrhizae on N Utilization by the Host-Plant: Myth or Reality ?, 209-240. doi: 10.1007/978-3-540-78826-3_11.

Gonçalves, J.L.D.M., Alvares, C.A., Higa, A.R., Silva, L.D., Alfenas, A.C., Stahl, J., Ferraz, S.F.D.B., Lima, W.D.P., Brancalion, P.H.S., Hubner, A., Bouillet, J.P.D., Laclau, J.P., Nouvellon, Y., Epron, D., 2013. Integrating genetic and silvicultural strategies to minimize abiotic and biotic constraints in Brazilian eucalypt plantations. Forest Ecol. Manage. 301, 6-27. http://dx.doi.org/10.1016/j.foreco.2012.12.030.

Göransson, H., Wallander, H., Ingerslev, M., Rosengren, U., 2006. Estimating the relative nutrient uptake from different soil depths in Quercus robur, Fagus sylvatica and Picea abies. Plant Soil 286, 87-97. http://dx.doi.org/10.1007/s11104-006-9028-0.

Göransson, H., Fransson, A.M., Jönsson-Belyazid, U., 2007. Do oaks have different strategies for uptake of N, K and P depending on soil depth? Plant Soil 297, 119-125. http://dx.doi.org/10.1007/s11104-007-9325-2.

Göransson, H., Ingerslev, M., Wallander, H., 2008. The vertical distribution of N and K uptake in relation to root distribution and root uptake capacity in mature Quercus robur, Fagus sylvatica and Picea abies stands. Plant Soil 306, 129-137. http://dx.doi. org/10.1007/s11104-007-9524-X.

Gu, Y., Wang, Y., Lu, S., Xiang, Q., Yu, X., Zhao, K., Zou, L., Chen, Q., Tu, S., Zhang, X., 2017. Long-term fertilization structures bacterial and archaeal communities along soil depth gradient in a paddy soil. Front. Microbiol. 8, 1-15. http://dx.doi.org/10 3389/fmicb.2017.01516.

Guo, D., Xia, M., Wei, X., Chang, W., Liu, Y., Wang, Z., 2008. Anatomical traits associated with absorption and mycorrhizal colonization are linked to root branch order in twenty-three Chinese temperate tree species. New Phytol. 180, 673-683. http://dx doi.org/10.1111/j.1469-8137.2008.02573.x.

He, P., Wan, S.Z., Fang, X.M., Wang, F.C., Chen, F.S., 2016. Exogenous nutrients and carbon resource change the responses of soil organic matter decomposition and nitrogen immobilization to nitrogen deposition. Sci. Rep. 6, 1-11. http://dx.doi.org/ 10.1038/srep23717.

Hinsinger, P., Brauman, A., Devau, N., Gérard, F., Jourdan, C., Laclau, J.P., Le Cadre, E., Jaillard, B., Plassard, C., 2011. Acquisition of phosphorus and other poorly mobile nutrients by roots. Where do plant nutrition models fail? Plant Soil 348, 29-61.

Hubbard, R.M., Ryan, M.G., Giardina, C.P., Barnard, H., 2004. The effect of fertilization on sap flux and canopy conductance in a Eucalyptus saligna experimental forest. Global Change Biol. 10, 427-436. http://dx.doi.org/10.1111/j.1529-8817.2003. 00741.x

Iversen, C.M., 2010. Digging deeper: fine-root responses to rising atmospheric $\mathrm{CO}_{2}$ concentration in forested ecosystems. New Phytol. 186, 346-357. http://dx.doi.org/10. 1111/j.1469-8137.2009.03122.x.

Jourand, P., Hannibal, L., Majorel, C., Mengant, S., Ducousso, M., Lebrun, M., 2014. Ectomycorrhizal Pisolithus albus inoculation of Acacia spirorbis and Eucalyptus globulus grown in ultramafic topsoil enhances plant growth and mineral nutrition while limits metal uptake. J. Plant Physiol. 171, 164-172. http://dx.doi.org/10.1016/j.jplph. 2013.10.011.

Keenan, R.J., Reams, G.A., Achard, F., de Freitas, J.V., Grainger, A., Lindquist, E., 2015. Dynamics of global forest area: results from the FAO global forest resources assessment 2015. Forest Ecol. Manage. 352, 9-20. http://dx.doi.org/10.1016/j.foreco. 2015.06.014.

Kiba, T., Krapp, A., 2016. Plant nitrogen acquisition under low availability: regulation of uptake and root architecture. Plant Cell Physiol. 57, 707-714. http://dx.doi.org/10. 1093/pcp/pcw052.

Kong, D., Wang, J., Zeng, H., Liu, M., Miao, Y., Wu, H., Kardol, P., 2017. The nutrient absorption-transportation hypothesis: optimizing structural traits in absorptive roots. New Phytol. 213, 1569-1572. http://dx.doi.org/10.1111/nph.14344.

Kulmatiski, A., Adler, P.B., Stark, J.M., Tredennick, A.T., 2017. Water and nitrogen uptake are better associated with resource availability than root biomass. Ecosphere 8, 1-10. http://dx.doi.org/10.1002/ecs2.1738.

Laclau, J.P., Sama-Poumba, W., Nzila, J.D.D., Bouillet, J.P., Ranger, J., 2002. Biomass and nutrient dynamics in a littoral savanna subjected to annual fires in Congo. Acta Oecol. 23, 41-50. http://dx.doi.org/10.1016/S1146-609X(02)01132-3.

Laclau, J.-P., Almeida, J.C.R., Gonçalves, J.L.M., Saint-André, L., Ventura, M., Ranger, J., Moreira, R.M., Nouvellon, Y., 2009. Influence of nitrogen and potassium fertilization on leaf lifespan and allocation of above-ground growth in Eucalyptus plantations. Tree Physiol. 29, 111-124. http://dx.doi.org/10.1093/treephys/tpn010.

Laclau, J.P., Ranger, J., de Moraes Gonçalves, J.L., Maquère, V., Krusche, A.V., M'Bou, A.T., Nouvellon, Y., Saint-André, L., Bouillet, J.P., de Cassia Piccolo, M., Deleporte, P., 2010. Biogeochemical cycles of nutrients in tropical Eucalyptus plantations. Main features shown by intensive monitoring in Congo and Brazil. Forest Ecol. Manage. 259, 1771-1785. http://dx.doi.org/10.1016/j.foreco.2009.06.010.

Laclau, J.P., da Silva, E.A., Rodrigues Lambais, G., Bernoux, M., Le Maire, G., Stape, J.L., Bouillet, J.-P., Gonçalves, J.L.D.M., Jourdan, C., Nouvellon, Y., 2013. Dynamics of soil exploration by fine roots down to a depth of $10 \mathrm{~m}$ throughout the entire rotation in Eucalyptus grandis plantations. Front. Plant Sci. 243, 1-12. http://dx.doi.org/10. 3389/fpls.2013.00243.

Lehmann, J., 2003. Subsoil root activity in tree-based cropping systems. Plant Soil 255, 319-331. http://dx.doi.org/10.1023/A:1026195527076.

Leuschner, C., Hertel, D., Schmid, I., Koch, O., Muhs, A., Hölscher, D., 2004. Stand fine root biomass and fine root morphology in old-growth beech forests as a function of precipitation and soil fertility. Plant Soil 258, 43-56. http://dx.doi.org/10.1023/ B:PLSO.0000016508.20173.80.

Li, C., Yan, K., Tang, L., Jia, Z., Li, Y., 2014. Change in deep soil microbial communities due to long-term fertilization. Soil Biol. Biochem. 75, 264-272. http://dx.doi.org/10. 1016/j.soilbio.2014.04.023.

Maathuis, F.J.M., Sanders, D., 1996. Mechanisms of potassium absorption by higher plant roots. Physiol. Plant. 96, 158-168. http://dx.doi.org/10.1111/j.1399-3054.1996. tb00197.x.

Maeght, J.-L., Rewald, B., Pierret, A., 2013. How to study deep roots-and why it matters Front. Plant Sci. 4, 1-14. http://dx.doi.org/10.3389/fpls.2013.00299.

Maquère, 2008. Dynamics of mineral elements under a fast-growing Eucalyptus plantation in Brazil. Implication for soil sustainability. Ph.D. Thesis, AgroParitech, Paris, p. 369, < https://pastel.archives-ouvertes.fr/file/index/docid/610330/filename/ These_VM.pdf $>$

Mareschal, L., Laclau, J.P., Nzila, J.D.D., Versini, A., Koutika, L.S., Mazoumbou, J.C., Deleporte, P., Bouillet, J.P., Ranger, J., 2013. Nutrient leaching and deep drainage under Eucalyptus plantations managed in short rotations after afforestation of an African savanna: two 7-year time series. Forest Ecol. Manage. 307, 242-254. http:// dx.doi.org/10.1016/j.foreco.2013.06.038.

Maurice, J., Laclau, J.-P., Scorzoni, R.E.D., Gonçalves, J.L.D.M., Nouvellon, Y., Bouillet, J.-P., Stape, J.L., Ranger, J., Behling, M., Chopart, J.-L., 2010. Fine root isotropy in Eucalyptus grandis plantations. Towards the prediction of root length densities from root counts on trench walls. Plant Soil 334, 261-275. http://dx.doi.org/10.1007/ s11104-010-0380-8.

Mayor, J., Bahram, M., Henkel, T., Buegger, F., Pritsch, K., Tedersoo, L., 2015. Ectomycorrhizal impacts on plant nitrogen nutrition: emerging isotopic patterns, latitudinal variation and hidden mechanisms. Ecol. Lett. 18, 96-107. http://dx.doi. org/10.1111/ele.12377.

McCormack, M.L., Dickie, I.A., Eissenstat, D.M., Fahey, T.J., Fernandez, C.W., Guo, D. Helmisaari, H.S., Hobbie, E.a., Iversen, C.M., Jackson, R.B., Leppalammi-Kujansuu, J., Norby, R.J., Phillips, R.P., Pregitzer, K.S., Pritchard, S.G., Rewald, B., Zadworny, M., 2015. Redefining fine roots improves understanding of below-ground contributions to terrestrial biosphere processes. New Phytol. 207, 505-518. http://dx.doi. org $/ 10.1111 /$ nph.13363.

McElrone, A.J., Pockman, W.T., Martínez-Vilalta, J., Jackson, R.B., 2004. Variation in xylem structure and function in stems and roots of trees to $20 \mathrm{~m}$ depth. New Phytol. 163, 507-517. http://dx.doi.org/10.1111/j.1469-8137.2004.01127.x.

Nadelhoffer, K.J., 2000. The potential effects of nitrogen deposition on fine-root production in forest ecosystems. New Phytol. 147, 131-139. http://dx.doi.org/10.1046/ j.1469-8137.2000.00677.x.

Nepstad, D.C., De Carvalho, C.R., Davidson, E.A., Jipp, P.H., Lefebvre, P.A., Negreiros, G.H., Da Silva, E.D., Stone, T.A., Trumbore, S.E., Vieira, S., 1994. The role of deep roots in the hydrological and carbon cycles of Amazonian forests and pastures. Nature 372, 666-669.

Ostonen, I., Püttsepp, Ü., Biel, C., Alberton, O., Bakker, M.R., Lõhmus, K., Majdi, H., Metcalfe, D., Olsthoorn, A.F.M., Pronk, A., Vanguelova, E., Weih, M., Brunner, I., 2007. Specific root length as an indicator of environmental change. Plant Biosyst. 141, 426-442. http://dx.doi.org/10.1080/11263500701626069.

Paquette, A., Messier, C., 2010. The role of plantations in managing the world's forests in the Anthropocene. Front. Ecol. Environ. 8, 27-34. http://dx.doi.org/10.1890/ 080116.

Pate, J.S., Jeschke, W.D., Aylward, M.J., 1995. Hydraulic architecture and xylem structure of the dimorphic root systems of South-West Australian species of Proteaceae. J. Exp. Botany 46, 907-915. http://dx.doi.org/10.1093/jxb/46.8.907.

Pinheiro, R.C., de Deus, J.C., Nouvellon, Y., Campoe, O.C., Stape, J.L., Aló, L.L., Guerrini, I.A., Jourdan, C., Laclau, J.P., 2016. A fast exploration of very deep soil layers by Eucalyptus seedlings and clones in Brazil. Forest Ecol. Manage. 366, 143-152. http:// dx.doi.org/10.1016/j.foreco.2016.02.012.

Plassard, C., Véry, A., Casarin, V., Thibaud, J., 2002. Local measurements of nitrate and potassium fluxes along roots of maritime pine. Effects of ectomycorrhizal symbiosis. Plant Cell Environ. 25, 75-84. http://dx.doi.org/10.1046/j.0016-8025.2001. 00810.x.

Pradier, C., Hinsinger, P., Laclau, J.P., Bouillet, J.P., Guerrini, I.A., Gonçalves, J.L.M., Asensio, V., Abreu-Junior, C.H., Jourdan, C., 2016. Rainfall reduction impacts rhizosphere biogeochemistry in eucalypts grown in a deep Ferralsol in Brazil. Plant Soil 414, 339-354. http://dx.doi.org/10.1007/s11104-016-3107-7.

Pregitzer, K.S., DeForest, J.L., Burton, A.J., Allen, M.F., Ruess, R.W., Hendrick, R.L., 2002 Fine root architecture of nine North American trees. Ecol. Monographs 72, 293-309. http://dx.doi.org/10.2307/3100029.

Prieto, I., Roumet, C., Cardinael, R., Dupraz, C., Jourdan, C., Kim, J.H., Maeght, J.L., Mao, Z., Pierret, A., Portillo, N., Roupsard, O., Thammahacksa, C., Stokes, A., 2015. Roo functional parameters along a land-use gradient: evidence of a community-level economics spectrum. J. Ecol. 103, 361-373. http://dx.doi.org/10.1111/1365-2745. 12351.

R Core Team, 2013. R: A language and environment for statistical computing. $\mathrm{R}$ Foundation for Statistical Computing. < https://www.R-project.org/ >

Rowe, E.C., Smart, S.M., Kennedy, V.H., Emmett, B.A., Evans, C.D., 2008. Nitrogen deposition increases the acquisition of phosphorus and potassium by heather Calluna vulgaris. Environ. Pollut. 155, 201-207. http://dx.doi.org/10.1016/j.envpol.2007.12. 
008 .

Schachtman, D.P., Schroeder, J.I., 1994. Structure and transport mechanism of a highaffinity potassium uptake transporter from higher plants. Nature 370, 655-658. http://dx.doi.org/10.1038/370655a0.

Silva, P.H.M.D., Poggiani, F., Libardi, P.L., Gonçalves, A.N., 2013. Fertilizer management of eucalypt plantations on sandy soil in Brazil: initial growth and nutrient cycling. Forest Ecol. Manage. 301, 67-78. http://dx.doi.org/10.1016/j.foreco.2012.10.033.

Soethe, N., Lehmann, J., Engels, C., 2006. The vertical pattern of rooting and nutrient uptake at different altitudes of a south Ecuadorian montane forest. Plant Soil 286, 287-299. http://dx.doi.org/10.1007/s11104-006-9044-0.

Stape, J.L., Binkley, D., Ryan, M.G., Fonseca, S., Loos, R.a., Takahashi, E.N., Silva, C.R., Silva, S.R., Hakamada, R.E., Ferreira, J.M.D.A., Lima, A.M.N., Gava, J.L., Leite, F.P., Andrade, H.B., Alves, J.M., Silva, G.G.C., Azevedo, M.R., 2010. The Brazil eucalyptus potential productivity project: influence of water, nutrients and stand uniformity on wood production. Forest Ecol. Manage. 259, 1684-1694. http://dx.doi.org/10.1016/ j.foreco.2010.01.012.

Vanninen, P., Makela, A., 1999. Fine root biomass of Scots pine stands differing in age and soil fertility in southern Finland. Tree Physiol. 19, 823-830. http://dx.doi.org/10. 1093/treephys/19.12.823.

Versini, A., Mareschal, L., Matsoumbou, T., Zeller, B., Ranger, J., Laclau, J.P., 2014. Effects of litter manipulation in a tropical Eucalyptus plantation on leaching of mineral nutrients, dissolved organic nitrogen and dissolved organic carbon.

Geoderma 232-234, 426-436. http://dx.doi.org/10.1016/j.geoderma.2014.05.018.

Voigtlaender, M., Laclau, J.P., de Gonçalves, J.L.M., de Piccolo, M.C., Moreira, M.Z.,

Nouvellon, Y., Ranger, J., Bouillet, J.P., 2012. Introducing Acacia mangium trees in Eucalyptus grandis plantations: consequences for soil organic matter stocks and nitrogen mineralization. Plant Soil 352, 99-111. http://dx.doi.org/10.1007/s11104 011-0982-9.

Wang, Y., Dong, X., Wang, H., Wang, Z., Gu, J., 2015. Root tip morphology, anatomy, chemistry and potential hydraulic conductivity vary with soil depth in three temperate hardwood species. Tree Physiol. 36, 1-10. http://dx.doi.org/10.1093/ treephys/tpv094.

Wurzburger, N., Wright, S.J., 2015. Fine-root responses to fertilization reveal multiple nutrient limitation in a lowland tropical forest. Ecology 96, 2137-2146. http://dx. doi.org/10.1890/14-1362.1.

Yuan, Z.Y., Chen, H., 2010. Fine root biomass, production, turnover rates, and nutrient contents in boreal forest ecosystems in relation to species, climate, fertility, and stand age: literature review and meta-analyses. Crit. Rev. Plant Sci. 29, 204-221. http://dx. doi.org/10.1080/07352689.2010.483579.

Zuur, A.F., Ieno, E.N., Walker, N.J., Saveliev, A., Smith, G.M., 2009. Journal of Statistical Software. November, 32, 2-4. 